\title{
Human Behavior and the Law of Work
}

\section{Citation}

Cass R. Sunstein, Human Behavior and the Law of Work (John M. Olin Program in Law \& Economics Working Paper No. 100, 2000).

\section{Published Version}

http://chicagounbound.uchicago.edu/law_and_economics/243/

\section{Permanent link}

http://nrs.harvard.edu/urn-3:HUL.InstRepos:12876727

\section{Terms of Use}

This article was downloaded from Harvard University's DASH repository, and is made available under the terms and conditions applicable to Other Posted Material, as set forth at http:// nrs.harvard.edu/urn-3:HUL.InstRepos:dash.current.terms-of-use\#LAA

\section{Share Your Story}

The Harvard community has made this article openly available.

Please share how this access benefits you. Submit a story.

\section{Accessibility}




\section{University of Chicago Law School Chicago Unbound}

Coase-Sandor Working Paper Series in Law and

Economics

Coase-Sandor Institute for Law and Economics

2000

\section{Human Behavior and the Law of Work}

Cass R. Sunstein

Follow this and additional works at: http://chicagounbound.uchicago.edu/law_and_economics Part of the Law Commons

\section{Recommended Citation}

Cass R. Sunstein, "Human Behavior and the Law of Work" (John M. Olin Program in Law and Economics Working Paper No. 100, 2000).

This Working Paper is brought to you for free and open access by the Coase-Sandor Institute for Law and Economics at Chicago Unbound. It has been accepted for inclusion in Coase-Sandor Working Paper Series in Law and Economics by an authorized administrator of Chicago Unbound. For more information, please contact unbound@law.uchicago.edu. 


\section{HICAG 0}

JOHN M. OLIN LAW \& ECONOMICS W ORKING PAPER N 0. 100 (2D SERIES)

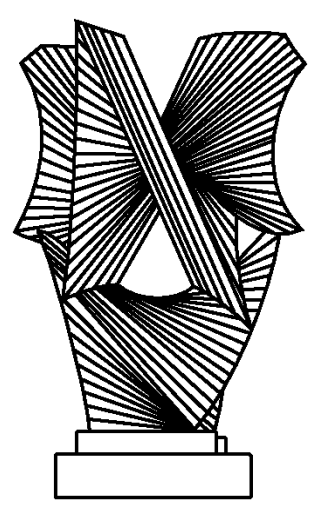

H uman Behavior and the Law of W ork

Cass R. Sunstein

THE LAW SCHOOL

THE UNIVERSITY OF CHICAGO

This paper can be downloaded without charge at the

Social Science Research N etwork E lectronic Paper Collection:

http://papers.ssrn.com/paper.taf?abstract_id=231922 


\title{
Preliminary draft 6/2/00
}

All rights reserved

\section{Human Behavior and the Law of Work}

\author{
Cass R. Sunstein*
}

\begin{abstract}
The most fundamental issues in labor and employment law involve the choice among three alternatives: waivable employers' rights, waivable employees' rights, and nonwaivable employees' rights. By combining standard contract analysis with a perspective informed by behavioral economics, it is possible to obtain a much better understanding of the underlying issues. Contrary to the conventional view: workers are especially averse to losses, and not so much concerned with obtaining gains; workers often do not know about legal rules, including key rules denying them rights; workers may well suffer from excessive optimism; workers care a great deal about fairness, and are willing to punish employers who have treated them unfairly, even at workers' own expense; many workers greatly discount the future; and workers often care about relative economic position, not absolute economic position. These points suggest the advantages, in many cases, of relying on waivable employees' rights, an approach designed to inform workers without providing the rigidity and inefficiency associated with nonwaivable terms. At the same time, these points suggest, though more ambiguously, the hazards of allowing workers to waive their rights in accordance with standard contract principles. Procedural constraints (e.g., cooling off periods) and substantive constraints (e.g., "floors") on waiver may be appropriate. Norm change and preference change are also discussed. Applications include job security; parental leave; vacation time; health care; unionization; occupational safety and health; discrimination on the basis of age, race, and sex; waivers by unions; and workers' compensation. The basic conclusion is that waivable employees' rights are a promising and insufficiently explored option in many areas of labor and employment law.
\end{abstract}

\section{Introduction}

\section{A. A Problem and A Proposal}

In allocating rights in the workplace, the law has many options. It might, for example, confer certain rights on employers, but allow employees to purchase those rights (to, say, health care or vacation time) through a voluntary trade. It might make certain employers' rights nonwaivable; it might say, for example, that an employee, or a group of employees, cannot buy an employer's right to donate money to political campaigns. It might give employees certain waivable rights, saying, for example, that an employee is presumed to have a right to at least four weeks of vacation each year, but that employers can buy that right through a suitable deal. Or it might give employees rights that cannot be waived, saying, for example, that no worker may be asked to trade the right to four weeks of vacation each year. There are many possible variations.

\footnotetext{
* Karl N. Llewellyn Distinguished Service Professor of Jurisprudence, University of Chicago Law School and Department of Political Science.
} 
The basic purpose of this Article is bring a better understanding of human behavior, with the assistance of cognitive psychology and behavioral economics, ${ }^{1}$ to bear on the most basic questions in employment law. ${ }^{2}$ I offer two general claims. The first is that waivable workers' rights represent a desirable approach for the future, partly because waivable rights lack the rigidity of nonwaivable ones, and partly because they ensure that the key information will be provided to workers. The second claim is that traditional approaches to employment law make many blunders, because they are based on an inadequate sense of workers' actual values and behavior. Contrary to the conventional wisdom: workers are especially averse to losses, and not so much concerned with obtaining gains; workers often do not know about legal rules, including key rules denying them rights; workers are likely to suffer from excessive optimism; workers care a great deal about fairness, and are willing to punish employers who have treated them unfairly, even at workers' own expense ${ }^{3}$; many workers greatly discount the future; and workers often care about relative economic position, not absolute economic position. In short, workers are like most people. They behave like homo sapiens, not like homo economicus. ${ }^{4}$

More specifically, I attempt to see how a more realistic understanding of workers' thoughts and actions, alongside suitably modified contractual principles, would help us to sort out the relevant inquiries in the choice among the four principal approaches to the law of labormanagement relations: (1) waivable employers' rights, (2) waivable workers' rights, (3) nonwaivable workers' rights, and (4) waivable workers' rights with constraints on permissible waiver. I suggest that in many situations, the law should confer certain entitlements on employees rather than employers, but allow those entitlements to be waived, either at a market price (an "unconstrained waiver") or subject to governmentally determined floors, whether procedural or substantive (a "constrained waiver"). The principal purpose of this approach is to ensure that employers fully disclose contractual terms to employees, and allow employees to waive only when waiver is thought to be worthwhile, without producing the rigidity and inefficiency, and potential harm to workers and consumers alike, that are created by systems of nonwaivable, "one-size-fits-all" terms. ${ }^{5}$

The basic idea could be applied to both unionized and non-unionized workplaces. It could even be applied to the question whether workers are collectively organized at all; a default rule might specify collective organization, and allow workers to opt out, rather than specifying the opposite, and allowing them to opt in. ${ }^{6}$ It is especially important to see that the default rule matters. What I will ultimately suggest is a kind of two-tiered system of employment law, involving (a) nonwaivable statutory minima, below which no workplace may go, and (b)

\footnotetext{
${ }^{1}$ See Richard Thaler, Quasi-Rational Economics (1991); Christine Jolls et al., A Behavioral Approach to Law and Economics, 50 Stan. L. Rev. 1471 (1998); Behavioral Law and Economics (Cass R. Sunstein ed. 2000).

${ }^{2}$ I use this term to refer to both "labor law," traditionally taken to refer to the law relating to unions and unionization, and "employment law," traditionally taken to refer to the law relating to statutory protections of workers.

${ }^{3}$ This is the basic theme of Truman Bewley, Why Wages Don't Fall During A Recession (2000).

${ }^{4}$ See Richard Thaler, From Homo Economicus to Homo Sapiens, J Ec Persp (2000).

${ }^{5}$ A system of nonwaivable terms is urged in Charles Fried, Individual and Collective Rights in Work Relations, 51 U Chi L Rev 1012 (1984); my criticisms of the more ad hoc system of modern statutory law would apply to Fried's general proposal as well.

${ }^{6}$ See Paul Weiler, Governing the Workplace (1993).
} 
waivable workers' rights, involving an ample set of safeguards that employers may "buy" for a mutually agreeable fee. ${ }^{7}$ The real questions should involve the content of the two categories.

\section{B. An Unduly Limited Debate}

In the workplace, as elsewhere, the law cannot "do nothing." ${ }^{, 8}$ For even the most enthusiastic believers in private property and freedom of contract, it is necessary to start somewhere, not with "nature" or voluntary arrangements but with an initial allocation of legal rights.

Most debates in American employment law have been framed narrowly and in terms of the three alternatives of waivable employers' rights, collective bargaining, and nonwaivable workers' rights. Under a system of waivable employers' rights, the law confers an initial entitlement on employers, but employees can "buy" the relevant right if they have both the desire and the leverage to do so. It is important to emphasize that the employer has these rights not by nature, and not as a result of anything consensual, but because of a distinctly legal decision, to confer the relevant rights on the employer rather than the employee. The right at issue might involve the most fundamental questions for workers: job security, workplace safety, pensions, health insurance, leave policy, vacation time, freedom from race, sex and age discrimination, and so forth.

This simple idea captures much of the common law of labor relations. ${ }^{9}$ The common law confers a wide range of entitlements on employers, subject to individual bargaining. The single exception is the labor power of the employee. ${ }^{10}$ Of course, the law grants employees, not employers, the right to the employee's time and labor. (Slavery is an obvious qualification.) This is a right that employees can and do trade for money and other benefits of employment. The flexibility of the common law approach is its great advantage. But it is not clear that most workers have the information that would equip them to engage in appropriate bargaining, and it is possible to think that many individual employees, bargaining with employers, will lack the knowledge or the power to produce efficient or fair deals without some form of collective organization. In any case the allocation of initial rights to employers remains to be defended.

\footnotetext{
${ }^{7}$ For a brief suggestion along the same lines for worker safety, see Susan Rose-Ackerman, Progressive Law and Economics, 98 Yale LJ 341, 358-60 (1988).

${ }^{8}$ See Guido Calabresi and A. Douglas Melamed, Property Rules, Liability Rules, and Inalienability: One View of the Cathedral, 85 Harv L Rev 1089, 1090 (1972).

${ }^{9}$ Described and defended in Richard A. Epstein, A Common Law for Labor Relations, 92 Yale LJ 1357 (1983).

What Epstein does not sufficiently acknowledge is the extent to which a number of rights are conferred on the employer by the common law; any suggestion that the common law reflects "laissez faire," or promotes "voluntary interactions," should be prefaced with this point. See in this vein Charles Fried, Individual and Collective Rights in Work Relations, 51 U Chi L Rev 1012, 1016 (1984): “Only by assuming that the preexisting common law system of property rights as some natural, preconventional status can the expropriatory thrust of the Wagner Act (to the extent that there is one) be criticized." A better way to put it would be to suggest that the very claim that there is an exproprietary thrust in the Wagner Act depends on the (implausible) claim that the common law system of property rights has some natural, preconventional status.

${ }^{10}$ Note the contrast with a system of slavery, in which the law confers on employers a right to employee labor. The employers' right is waivable in the sense that the employer can pay the slave a salary or even giant the slave freedom, perhaps in return for consideration.
} 
In the 1930s, the United States ventured a second approach to labor-management relations. This approach, embodied in the National Labor Relations Act $^{11}$ (NLRA), was a dramatic, even revolutionary step: a mechanism for solution of disagreements via collective bargaining. On this view, entitlements would generally begin in the same place where the common law put them, with employers. But workers would be allowed, even encouraged to organize as a group, and workplace management would be decided via a process of bargaining between employers and employees, thus organized. In some ways, the NLRA's arrangement is more complicated and more interesting. With respect to "mandatory" subjects of bargaining wages, hours, and working conditions - the NLRA can be understood to remove common law rights from employers and to create "bargaining entitlements," that is, entitlements that are not owned by anyone in particular but that will be a product of bargaining, having been selfconsciously placed, as an initial step, in the hands of neither side. ${ }^{12}$

This system of worker organization and collective rather than individual bargaining has been justified on many diverse grounds. ${ }^{13}$ Most obviously, collective bargaining would allow information to be shared and pooled among workers, and hence it would permit them to overcome the many evident barriers to informed bargaining. At the same time, union representation would resolve a collective action problem faced by individual workers, who would compete, perhaps to their collective detriment, in the process of seeking employment. ${ }^{14}$ Self-organization could create a kind of workers' cartel, justified on the ground that the result would be to extract better deals from employers (possibly at the expense of nonunionized workers). ${ }^{15}$ In any case many of the goods provided by employers - safety, decent lighting, heat, pension benefits, formal procedures in the event of arbitrary discharge - are "local public goods" in the sense that they cannot be provided by one without being simultaneously provided to all or most. In these circumstances a collective voice might ensure against the underproduction of such goods. ${ }^{16}$ Perhaps union representation would also respond to short-sightedness, or bounded rationality, on the part of individual workers, producing outcomes that would best serve their long-term interests. ${ }^{17}$ Perhaps collective organization was simply necessary to produce industrial peace. Whatever its goals, the collective bargaining approach has fallen on hard times with the

\footnotetext{
1129 USC 151 et seq.

${ }^{12}$ See Michael Wachter and George Cohen, The Law and Economics of Collective Bargaining, 136 U Pa L Rev 1349, 1371-74 (1988).

${ }^{13}$ The literature is immense. For summaries, see Richard Freeman and James Medoff, What Do Unions Do? ch. 1 (1984); Michael Harper and Samuel Estreicher, Labor Law 2-4 (1995).

${ }^{14}$ For an early statement, see John Stuart Mill, Principles of Political Economy 351(Jonathan Riley ed. 1994) ; see also Richard Posner, Some Economics of Labor Law, 51 U Chi L Rev 988 (1984); Richard Freeman and James Medoff, What Do Unions Do? 6-7 (1984).

${ }^{15}$ The "union wage premium" is generally estimated at $10 \%$ to $20 \%$, see Harper and Estreicher, supra note, at 14; Freeman and Medoff, supra, at 43-60. Unions also produce a mix in the compensation package, with particularly favorable effects on fringe benefits, see id. at 61-77. Thus unionized "establishments are especially likely to allot funds to deferred forms of compensation favoring senior workers, such as pensions, insurance, and vacation pay, and to have a large impact on smaller establishments." Id.at 77.

${ }^{16}$ Id. at $8-9$.

${ }^{17}$ For relevant evidence, see Freedman and Medoff, What Do Unions Do? (1984) (emphasizing distinct features to compensation packages favored by unions, placing emphasis on long-term problems).
} 
dramatic decline of union representation since the 1940s, a decline that obviously has something to do with workers' uncertainty about whether unionization would help or hurt them. ${ }^{18}$

The third approach involves nonwaivable employees' rights. Under this system, the law confers the relevant right on employees, and employers and employees are forbidden from contracting around the legal guarantee. The relevant right might be a right to protection from occupational risks; it might be a right to be free from discharge on grounds of race, sex, or age; it might be a right not to be discharged for engaging in collective bargaining or for refusing to violate the law on the employers' behalf. As a matter of history, the third approach seems largely a reaction to the first, fueled by complaints about employers' "bargaining power" and about the perceived injustice of the common law approach. ${ }^{19}$ This system dominates the current system of statutory protections for workers in $\mathrm{America}^{20}$; it also dominates the more aggressively workerprotective system of employment and labor law in Europe. The rise of nonwaivable employees' rights can be seen in part as a surrogate for a more robust system of collective bargaining. ${ }^{21}$ But at the same time, it can be seen as a way of relieving the pressure to create that very system. If statutory protections are in place, a union might seem unnecessary; the law is already giving employees what the union might have provided. A robust system of statutory guarantees would make union representation far less desirable. In addition, an approach based on nonwaivable workers' rights might be criticized on grounds of its rigidity; perhaps many workers could be better off with the flexibility to trade some goods for others, and perhaps consumers would benefit as well. ${ }^{22}$

\section{Workers' Rights, With Bargaining}

Several possibilities are missing from this picture. Most important: What if the law allocates the relevant entitlement to employees, but also makes the right waivable, in the sense that the employer could buy it, and the employee could sell it, for a fee? In principle, there is nothing at all strange about this idea. With respect to the employee's time, for example, the common law allocates rights in exactly this fashion; before employment, the individual has a property right (over the course of his day), but the employer can purchase the right for whatever amount the employee is willing to accept. We could easily imagine a system in which waivable workers' rights were a far larger part of the picture. For example, employees might have, but might be permitted to waive, rights not to be discharged without good cause; rights not to fired on grounds or race, sex, religion, and age; rights to health insurance and occupational safety; rights to parental leave; rights to vacation time; and much more. All of these rights would operate as default rules for employers to purchase if a mutually agreeable deal can be arranged.

\footnotetext{
${ }^{18}$ See Samuel Estreicher, Labor Law Reform in a World of Competitive Product Markets, 69 Chi-Kent L Rev 3 (1993).

${ }^{19}$ See, e.g., Lawrence Blades, Employment At Will vs. Individual Freedom, 67 Colum L Rev 1404 (1967).

${ }^{20}$ See, e.g., 29 USC 651 et seq. (Occupational Safety and Health Act); 29 USC 201 et seq (Fair Labor Standards Act, with minimum wage and maximum hour provisions); 42 USC 2000e-2000e-17 (Civil Rights Act of 1964, Title VII); 29 USC 2601 et seq. (Family and Medical Leave Act).

${ }^{21} \mathrm{Cf}$. Charles Fried, supra note (arguing for a statement of nonwaivable entitlements as a replacement for collective bargaining). Fried's argument is criticized in Cass R. Sunstein, Rights, Minimal Terms, and Solidarity, 51 U Chi L Rev. 1041 (1984).

${ }^{22}$ This is a generalization of the argument in Richard Epstein, Forbidden Grounds (1995).
} 
Waiver might operate individually or collectively; the law may or may not impose constraints on waivers.

What is absent from the traditional account is not only a full sense of the legal possibilities, but also an adequate picture of workers' judgments and motivations. To the extent that analysis of labor law has worked from any such picture, it is the one found in traditional economics. ${ }^{23}$ But we know enough to know that this picture is inaccurate. Indeed, we know a great deal about how it is inaccurate, and about what must be done to make it more nearly correct. $^{24}$ I attempt here to bring a better understanding of human behavior to bear on the various alternatives.

The Article comes in eight parts. Part II discusses the debate over "at will" employment, with reference to emerging developments that suggest a possible waivable right to be discharged for cause. Part III discusses some arguments for a nonwaivable background rule, the standard approach in modern statutory law. Part IV generalizes the idea of waivable workers' rights by briefly exploring a number of contemporary questions in employment law. Part V discusses problems with that idea, with particular reference to third party effects, information-processing, and collective efforts to change norms and values. Part VI discusses the difference between individual waivers and union waivers. Part VII deals with the fact that workers care partly about relative economic position, and not only about absolute economic position $-\mathrm{a}$ fact that helps support the idea of nonwaivable terms. Part VIII is a brief conclusion.

\section{An Illustration: The At Will Debate}

The debate over the contract at will has recently become one of the liveliest in all of private law. ${ }^{25}$ In some ways this debate is unique, for reasons that I will discuss in some detail; but it also has features in common with related debates involving parental leave, vacation time, health care, age discrimination, and much more. With the large decline in private-sector unions, ${ }^{26}$ the common law is now a principal arena for new contests about the nature of management-labor relations, and the permissible grounds for discharge under the evolving common law have thus received a great deal of judicial as well as academic attention. ${ }^{27}$ My particular goal is to show how a better understanding of human behavior casts new light on the issue, ${ }^{28}$ in a way that unequivocally suggests the hazards of relying on a system of waivable employers' rights, and that also suggests, though more equivocally, the value of creating waivable employees' rights instead.

\footnotetext{
${ }^{23}$ See, e.g., id.

${ }^{24}$ For an overview, see Richard Thaler, Quasi-Rational Economics (1991); see also Behavioral Law and Economics (Cass R. Sunstein ed. 2000).

${ }^{25}$ For discussion, see Stewart Schwab, Life-Cycle Justice, 92 Mich L. Rev. 8 (1993); Richard Epstein, U Chi L Rev (1984); Pauline Kim, Norms, Learning, and Law, 1999 Univ of Ill L Rev 447; Pauline Kim, Bargaining With Imperfect Information: A Study of Worker Perceptions of Legal Protection in an At-Will World, 83 Cornell L Rev 105 (1997); Paul Weiler, Governing the Workplace (1991).

${ }^{26}$ See Estreicher, supra note. The percentage has fallen from about 35\% in 1945 to about $10 \%$ in 2000.

${ }^{27}$ See Samuel Issacharoff, Contracting For Employment, 74 Tex L Rev 1783 (1996).

${ }^{28}$ As far as I am aware, the only existing discussion of the contract at will, from the point of view, can be found in the illuminating discussion in id.
} 


\section{A. Background and Movement}

In America, the general rule is of course that employment is "at will"; an employer can fire an employee for any reason or for no reason at all. In the last decades, however, courts have made three inroads on this rule. First, they have created a set of "public policy" exceptions to the at will rule. ${ }^{29}$ Hence an employer may not discharge an employee for refusing to commit a crime on his behalf. A key organizing idea here is that when a third party interest is at stake, there is an exception to the at will principle. ${ }^{30}$ Second, courts have found an implied "covenant of good faith and fair dealing," an idea that seems to forbid opportunistic discharges -- as, for example, when an employer discharges an employee before receiving a commission, a pension, or some other benefit that seems to have been earned. ${ }^{31}$ The best rationale for these decisions is that they violate implicit contractual understandings. ${ }^{32}$ Third - and as we shall see, most interesting for current purposes - courts have made some movement toward "inferring" a contractual term of job security on the basis of ambiguous commitments from employers, such as a vague promise (referring to "permanent employment") and employee manuals (even those that contain express disclaimers). ${ }^{33}$ In many states, the law is in flux. Montana has enacted a statutory program designed to replace the at will rule with a nonwaivable for cause regime, ${ }^{34}$ and in 1991 , the National Conference of Commissions on State Laws adopted a similar rule as the Uniform Employment Termination Act. ${ }^{35}$

\section{B. Of Waiver and Default Rules: Does It Matter Who Has The Entitlement?}

Under the at will rule, the common law confers the relevant entitlement on the employer. But entirely within a system of freedom of contract, it would be equally possible to confer the entitlement on the worker. Might it be sensible to give workers protection against discharge without cause, but to allow them to waive that protection for an agreed-upon price ${ }^{36}$ ? The initial question is whether, in a regime of freedom of contract, the default rule matters at all.

1. The endowment effect and "sticky" default rules. The Coase theorem says that if transactions costs are zero, the initial allocation of the entitlement does not matter. ${ }^{37}$ The Coase theorem actually suggests two different points. First: Whatever the content of the legal rule, the

\footnotetext{
${ }^{29}$ See, e.g., Brigham v. Dillon Cos., Inc., 935 P.2d 1035, 1059-60 (1997); Petermann v. International Brotherhood of Teamsters, 344 P.2d 25 (1959); Remington Freight Lines v. Larkey, 644 NW2d 931 (Ind. App. 1994); Belline v. KMart Corp., 940 F.2d 184 ( $7^{\text {th }}$ Cir. 1991).

${ }^{30}$ See Stewart Schwab, Wrongful Discharge Law and the Search for Third Party Effects, 74 Tex. L. Rev. 1943 (1994).

${ }^{31}$ Merrill v. Crothall-American, 606 A.2d 96 (Del. 1992); Hoffman La Roche v. Campbell, 512 So. 2 d 725 (Ala. 1987); K Mart Corp. v. Ponsock, 732 P.2d 1364 (1987). Fortune v. National Cash Register Co., 364 NE2d 1251 (1977).

${ }^{32}$ See Schwab, supra note.

${ }^{33}$ See below.

${ }^{34}$ Mont. Code Ann. 39-2-901 (1997)

${ }^{35}$ Model Employment Termination Act, reprinted in Mark Rothstein and Lance Liebman, Employment Law $208-19$ (1997) Statutory Supplement).

${ }^{36}$ The possibility is omitted in the discussion in Epstein, supra note; Richard Posner, Economic Analysis of Law 358-59 ( $5^{\text {th }}$ ed. 1998), apparently on the emphatically false assumption that it would be no different from a waivable employers' right.

${ }^{37}$ See Ronald Coase, The Problem of Social Cost. 3 J Law and Econ 1 (1960).
} 
parties will bargain their way to the efficient solution. Second: Whatever the content of the legal rule, the parties will bargain their way to the same solution. If these points are right, it does not matter, assuming no transactions costs, whether an employer or an employee is given the relevant entitlement. The question is how the Coase theorem bears on the selection of default rules in the context of employment law.

Let us begin by supposing that with respect to contracting around the job security term, transactions costs are zero. Is the Coase theorem correct? It is clear that the theorem is on firm ground insofar as it suggests that the parties will bargain their way to an efficient result, whatever the content of the legal rule. This is very close to a definition of efficiency. If the employer very much wants an at will rule, and if the employee does not care much about job security, the contract will provide for at will employment, regardless of the content of the legal rule. If the background rule is at will, there will be no contractual shift; if the background rule is for cause, the parties will bargain their way to an at will situation. Efficiency will follow no matter what the legal rule is. ${ }^{38}$

Will the legal rule be not merely efficient but also the same? Notwithstanding the Coase theorem, there is good reason to think that it will not be. ${ }^{39}$ The principal reason is the endowment effect, in accordance with which people tend to place a far higher value on an object if it is initially allocated to them than if it is initially allocated to someone else. ${ }^{40}$ Default rules have a tendency to stick, in labor contracts as elsewhere. If people are initially given a right to a certain good, they are likely to ask more to give it up than they would be willing to pay for it in the first instance. ${ }^{41}$ If for cause protection is initially given to the employee, it seems reasonable to predict that the employee will demand more to relinquish job security than he would be willing to pay to obtain the right in the first instance. If a right to discharge at will is given to employers, it follows that employers will demand more to give it up than they would pay to purchase it in the first instance. Thus the allocation of the legal entitlement, to workers or to employers, will likely matter in the sense that the ultimate outcome will be affected by the increased value placed upon the right simply by virtue of the initial allocation. ${ }^{42}$

So long as the right is initially allocated to one or another side, an endowment effect cannot be avoided; but much more thought needs to be given to the question how to select a default rule in the presence of endowment effects. This remains a largely unexplored question. Here are some relevant considerations:

\footnotetext{
${ }^{38}$ Of course the legal rule may have distributional consequences. If the employment right at issue is a large part of the wealth of either side, its allocation to one or another side will contribute to relative wealth. But in this context, it is difficult to see how the choice of one or another waivable rule will have significant distributive effects. So long as the parties can bargain, workers are not going to be poorer or richer if the default rule is one way rather than the other.

${ }^{39}$ See Richard Thaler, Quasi-Rational Economics (1993).

${ }^{40}$ For evidence in the area of default rules, see Russell Korobkin, Behavioral Economics, Contract Formation, and Contract Law, in Behavioral Law and Economics 116 (Cass R. Sunstein ed. 2000).

${ }^{41}$ See id.

${ }^{42}$ Compare the suggestion in R. Posner, supra note, at 359: "If the requirement were optimal it would be negotiated voluntarily." The suggestion is not wrong, but it neglects the possibility that the initial allocation of the right will determine what it is optimal.
} 
- Whether one or another endowment effect is to be preferred cannot be decided on standard efficiency grounds. So long as transactions costs are zero, either allocation would produce efficiency. A less standard analysis, also aimed at efficiency, would ask who would gain most from one or another endowment effect. If, for example, workers, having been initially allocated for cause protection, would demand a great deal to give it up, and if employers, having been initially given at will protection, would be willing to sell job security for a small price, then we would have reason to believe that efficiency favors a for cause rule. The problem with this analysis is that it must usually be conducted in the absence of data, and involves some speculation about what people would do or prefer in (counterfactual) circumstances.

- The easiest cases for choosing one or another default rule involve third-party effects. Indeed, if there are significant third-party effects a nonwaivable rule would probably be best, so as to protect third parties. With job security, however, no such third-party effects are obvious. Compare the question how to handle rights to parental leave. Suppose that children benefit from parental leave requirements (a proposition that is not obviously true; if such requirements reduce wages and employment, children might be hurt as well). If so, the best approach is probably to create a nonwaivable right to parental leave.

- We might want to ask whether there is a distributional reason to favor one or another rule. I will take up this issue in more detail below. For the moment note two simple points. First, an allocation of the legal right to workers would tend to increase the wealth of workers as a class. Second, significant distributive effects should not be expected in this context, because the resource gain, from the initial allocation, is not a large part of workers' wealth.

- An important question is whether aside from efficiency and distribution, desirable social effects would follow from creating a "sticky" default rule of a certain kind. An endowment effect of one or another sort might be supported if it could be shown to have valuable effects on social attitudes and norms. If, for example, it were thought important to inculcate an attitude, on the part of workers, of support for the right of job security, the case for a waivable workers' right would be strengthened. The line between a very sticky default rule and a nonwaivable right might be one of degree rather than one of kind; I take up this point below.

2. Nonzero transactions costs: paper, information, signaling. Of course transactions costs are not zero in the context of employment contracts. Some costs are presented merely by virtue of the need to generate paper to contract around an undesired background rule. Some costs come from the phenomenon of signaling. ${ }^{43}$

a. Paper and information. If courts select a rule that most parties dislike, the paper costs, while unlikely to be huge, may not be trivial. It would be necessary to produce formal documents where silence would otherwise be sufficient. Probably more important are information costs. Employers are repeat players, and perhaps they have sufficient information to know what they are doing when they ask for or sign a waiver. But employees are frequently imperfectly informed, to say the least. ${ }^{44}$ If the legal right is allocated to employers, employees may refuse to ask for job security because they

\footnotetext{
${ }^{43}$ For general discussion, see Eric Posner, Law and Social Norms (2000); in the context of employment law, see the discussion of severance pay in Truman Bewley, Why Wages Don't Fall During A Recession 268-69 (2000).

${ }^{44}$ See Pauline Kim, supra note.
} 
already believe that they have it, or because they are unable to think well about the subject. The existence of information costs means that the initial allocation of the legal right might turn out to matter a great deal, both to efficiency and to the ultimate outcome. I will return to this point shortly.

b. Signaling. Signaling problems create special problems in the area of job security. An employer who is willing to offer job security might find that it is attracting marginal workers. ${ }^{45}$ At the same time, an employee who presses hard for job security might be signaling that he will deserve to be discharged. Even if employers and employees would generally be better off with a system of job security, many individual employers and individual employees will rationally refuse to negotiate for it. Note that these points apply to many contractual rights for which employees might bargain. An employee might fail to seek a right to parental leave, perhaps in the belief that such a right already exists, more likely with the thought that the very request would signal a lack of commitment to work. In these circumstances, a waivable employers' right is likely to stick even if it is undesirable. There is evidence that this happens with respect to severance pay; employees do not seek severance pay because doing so sends a bad signal. ${ }^{46}$ The same stickiness may well be true of a waivable employers' right.

These points do not demonstrate that one waivable rule is better than another. But they are sufficient to show that the choice of the default rule is likely to matter a great deal, both to efficiency and to ultimate outcomes,

\section{What Mimics the Market?}

Suppose, then, that the legal rule will indeed matter. Under the conventional approach, one with obvious implications for labor-management relations in general, courts should seek the default rule that best "mimics the market," in the sense that it is the rule that employers and employees, armed with adequate information, would generally seek. ${ }^{47}$ In the context of labor law, it is not entirely clear that the legal system should choose the approach that would mimic the market, even if it can identify that approach. Perhaps a different approach will redistribute resources in a desired direction, ${ }^{48}$ or will have a salutary effect on the formation of preferences. But let us begin by approaching the choice of the waivable term in the conventional terms.

1. The simple case for at will employment. Those who argue for a waivable employers' right claim that this is what employees and employers would generally seek, and thus that the existing background rule "mimics the market." ${ }^{49}$ On this view, employers have a strong reason to resist a for cause regime, partly in order to immunize themselves from illegitimate and even frivolous suits, and partly in order to ensure against shirking. Perhaps industrial custom supports

\footnotetext{
${ }^{45}$ See David I Levine, Just-Cause Employment Policies in the Presence of Worker Adverse Selection, 9 J. Lab. Econ. 294 (1991); Issacharoff, supra, at 1794-9.

${ }^{46}$ See Bewley, supra note, at 268-69.

${ }^{47}$ See, e.g., Epstein, supra note.

${ }^{48}$ See Christine Jolls, Accommodation Mandates, Stan. L. Rev. (forthcoming 2000).

${ }^{49}$ This is the basic argument in Epstein, supra note.
} 
this view; certainly employment at will seems to be the general rule. ${ }^{50}$ With an at will rule, employers can prevent costly litigation whenever someone is discharged. They can also counteract the risk of opportunistic behavior by employees, in the form of shirking. ${ }^{51}$ More particularly, the right to discharge on whatever grounds the employer likes operates as an obstacle to employee performance that falls well below what the employee is able to do - a special virtue in light of the fact that shirking is both hard to monitor and hard to prove to third parties. ${ }^{52}$ And because operating a for cause system is likely to be expensive, most employers, and most employees, are the beneficiaries of the at will rule.

For those who believe that at will is the market-mimicking rule, it is also important to emphasize that most employees are generally unlikely to object to this rule. In a market economy, employers are quite unlikely to fire employees for no reason ${ }^{53}$ It is costly to get rid of good workers, and employers who fire people for no reason will have some trouble replacing them, simply because arbitrary discharges will have harmful reputational consequences, thus leading prospective employees to seek work elsewhere. A separate point is that employees typically develop at least some degree of firm-specific human capital; they are worth more to their own employer than they would be worth to other employers, because they have experience with the firm, and they know something about its operations and expectations. The fact that employees have firm-specific capital creates a built-in safeguard against unmotivated discharges. ${ }^{54}$

If employers generally would lose a great deal from a for cause system, and if employees generally would gain little, the at will rule stands adequately defended, as a background rule that replicates the likely result of bargaining. The only people who stand to gain from a for cause system are marginal workers, prominently including those who deserve to be discharged for poor job performance, but who would be immunized, in practice, by an at will system.

2. Problems. However plausible, this argument is not obviously correct; it depends on contentious empirical assumptions. Suppose, for example, that a for cause regime would not much affect employer practices, because in any sensibly designed system, discharge could occur at low cost whenever cause existed, and precisely because employers have little interest in discharging people for a reason other than cause. ${ }^{55}$ If for cause discharge is the ordinary practice, and if arbitrary discharges are infrequent, employees should have little to lose from a legal rule that requires cause -- unless (and perhaps this is the key point) the costs of administering a forcause regime turn out to be high. But where cause exists, employees would of course lose their suit in any case, and hence they are likely to bring suit, especially in light of the cost of doing so. A mechanism that pushes contests toward low-cost resolution -- such as arbitration - should ensure that employers have little to fear from a for cause regime. For all these reasons, it is

\footnotetext{
${ }^{50}$ See J. Holt Verkerke, An Empirical Perspective on Indefinite Term Employment Contracts, 1995 Wis. L. Rev. 837.

${ }^{51}$ See Schwab, supra note.

${ }^{52}$ See id.

${ }^{53}$ See R. Posner, supra note, at 358-59.

${ }^{54}$ See id.

55 This appears to be the aspiration of the Montana system, which encourages arbitration, and hence low-cost litigation. See Mont. Code Ann. 29-2-901 (1997).
} 
unclear that employers would greatly prefer an at will system to a sensibly designed for cause system.

At the same time, it is reasonable to suppose that many employees might well care a great deal about obtaining for cause protection, if only to obtain immunity from employer malice or mistake. Employee concern is likely to be greatest in late career, when opportunistic discharges become more probable; it is here that employers have special incentives to discharge employees, in violation of an implicit deal. ${ }^{56}$ But even earlier, employees are likely to be willing to pay something for job security (or to require employers to pay something to take it away). On this view, a for cause regime might be the best market-mimicking approach. Crucial empirical issues here involve, first, the cost of operating a for cause system and, second, the extent to which employees would actually be at risk in an at will system.

Because a final answer would turn on resolving those empirical issues, nothing said here demonstrates that a waivable workers' right would be the market-mimicking solution - that such an approach would actually reflect the outcome of informed bargaining by most employers and employees. But enough has been said to show that any judgment on that point depends on empirical questions that cannot be answered by a priori arguments.

3. Informational problems. An additional weakness of the argument that an at will system is market-mimicking has to do with informational problems. Above all, employees are apparently unaware that in the face of contractual silence, they are entering into an at will arrangement. Even if they know the basic fact, they may not understand exactly what it means.

Recent evidence, compiled by Pauline Kim, strongly suggests that workers believe that employment is generally for cause, not at will, and that discharge is therefore unlawful unless there is a job-related reason for it. ${ }^{57}$ In Missouri, for example, Kim found that extremely strong majorities of employees $-80 \%$ or more - believe that the following grounds for discharge, entirely lawful in Missouri, are in fact unlawful: the employer wants to hire someone else to do the same job; the employer mistakenly believes that the employee stole money; the employer personally dislikes the employee. ${ }^{58}$ Similar results were found in California and New York, notwithstanding substantial variations in the law of the three states. ${ }^{59}$ The most general finding is that overwhelming majorities falsely believe that discharges that fall short of good cause are prohibited by law. ${ }^{60}$

\footnotetext{
${ }^{56}$ See Schwab, supra.

${ }^{57}$ See Kim, supra note.

${ }^{58}$ Id. at 134.

591999 U Ill L Rev at 451.

${ }^{60}$ The point casts doubt on Judge Posner's suggestion that in the context of job security, there "are not the sort of information problems that might be defeat transactions over workplace safety, for discharges are not such rare events that workers can't be expected to evaluate the risk rationally." R. Posner, supra note, at 359. If workers believe that the legal rule already protects them, they are unlikely to try to bargain for job security. As discussed below, there are other problems with the suggestion that risks will be evaluated rationally in this context. One of my principal points here is that claims like that of Judge Posner are empirical ones, to be assessed empirically, and cannot be asserted a priori.
} 
Why do workers misstate the law? As Kim notes, it is possible that workers' belief to this effect is based on an understanding of workplace norms, rather than law. ${ }^{61}$ Perhaps the informal law of the workplace bars arbitrary discharges, even when state law does not. ${ }^{62}$ This is certainly possible; but why would workers say that what employers can do, as a matter of law, is the same as what they actually do, as a matter of practice? Behavioral economics and cognitive psychology suggest some possibilities. People tend to be optimists, and they often engage in wishful thinking ${ }^{63}$; they like to reduce cognitive dissonance, by drawing their beliefs about how things should be in line with their views about how things are. But I suggest a more particular hypothesis, one that remains to be tested. People's beliefs about what the law is are likely to reflect their beliefs about what the law should be. But for present purposes, the key point is simple: The fact that workers believe that they have legal protection against arbitrary discharge much weakens the suggestion that an at will default rule accurately captures the shared understanding of the parties.

\section{The Information-Eliciting Default Rule: A Waivable Workers' Right}

If we are uncertain about what rule would mimic the market, we might seek a background rule that operates not to mimic the market but to elicit information - that imposes on one or another of the parties the obligation to provide the crucial information to the other side (and also to courts). ${ }^{64}$ On which party should this burden be imposed? It makes obvious sense to say that employers can more cheaply propose a provision that will make matters clear. A simple conclusion follows: If employers really would like a system of at will employment, then courts should say that the background rule is for cause, simply in order to elicit, from them, a clear statement to this effect, so that both parties to the contract know its real content. ${ }^{65}$

In the abstract, this view might be defended simply on the ground that a choice of the market-mimicking rule depends on empirical issues that have not been resolved. Without evidence, and without reason to believe that evidence would strongly support one or another solution, an information-forcing rule seems best. But Kim's findings provide further support for this view. They are devastating to the idea that employees know that this is the rule, and enter into contracts with their eyes wide open. They strongly support the suggestion that the appropriate background rule is for cause, not to mimic the market, but so as to ensure that employers furnish the relevant information to the employee, and obtain a waiver if they can.

The essential argument for a waivable workers' right to job security is now in place. We lack much ground for confidence about the content of a market-mimicking rule. Lacking that confidence, a for cause regime seems best, as a way of forcing disclosure and overcoming what appears to be a lack of information on the part of workers. And if the argument is sound, it applies in many areas of labor and employment law, as we shall shortly see.

\footnotetext{
${ }^{61} \mathrm{Id}$.

${ }^{62}$ See Kim, supra note.

${ }^{63}$ See Shelley Taylor, Positive Illusions (1992).

${ }^{64}$ See Ian Ayres and Robert Gertner, Filling Gaps in Incomplete Contracts: An Economic Theory of Default Rules, 99 Yale LJ 87 (1989).

${ }^{65}$ See id.
} 


\section{E. Doctrinal Support}

These suggestions are not entirely without doctrinal support. In the last two decades, courts have moved in the direction of creating an informational-forcing default rule for job security. Mere silence does not create a waivable workers' right. But ambiguous statements, plausibly taken as conferring job security, are often taken to prevent at will discharge; and if employers are to escape that result, they must do so via a disclaimer that is exceedingly clear.

1. Old law. For many decades, an apparent but ambiguous promise by an employer would not create a contractual obligation to provide security. ${ }^{66}$ Employment manuals, for example, would not count as part of any contractual relationship. In the same vein, a statement by an employer or a personnel manager to the effect that the employee could work "as long as he did a good job," or "permanently," would not provide a for cause guarantee, at least if it was unaccompanied by a defined term for employment.

These results seem odd; they treat a promise apparently giving something to an employee as if it had no meaning at all. How might the pattern of decisions be explained? One possibility is that courts, in the relevant cases, are making a claim about the reasonable expectations of most parties, having made or heard statements of this sort. Perhaps an employee who has been told that he has "permanent" employment does not reasonably understand this as a promise, rather than a hope or expectation. But another, more interesting possibility is that courts are creating a kind of information-forcing default rule, to the effect that ambiguous statements will not create a for cause situation, and employees must obtain greater clarity if this is in fact what they want. A justification for this seemingly harsh result is that it prevents both parties and judges from guessing about the meaning of words that cannot really be taken as face value. An oral reference to "permanent" employment cannot mean that the employer will be allowed to work there forever; the statement must be qualified in various ways, and perhaps the court does not want to have to do the qualifying on its own. Treating the promise as a kind of goal, rather than a promise, prevents judicial guessing-games.

2. New law. But the law has changed a great deal, along these dimensions, in the last two decades. Courts have read employment manuals to create enforceable obligations, even when the relevant terms have ambiguity (as in, it is "the policy" of the company to fire people for cause). In Toussaint v. Blue Cross,${ }^{67}$ for example, the personnel manual said, in general terms, that it "is the policy of the company to treat employees in a fair and consistent manner and to release employees for just cause only." It was clear that under longstanding law, this statement would not be sufficient to overcome the at will presumption, in part because no term of years was identified. Nonetheless, the Michigan Supreme Court held that this was sufficient to create an obligation of continued employment, notwithstanding the absence of a specified term of years.

Indeed, some cases have entrenched the relevant provisions, to the extent that a disclaimer is unlikely to be effective unless it is exceptionally clear. Thus, for example, the Wyoming Supreme Court was confronted with an employee handbook containing the following language: "READ CAREFULLY BEFORE SIGNING. I agree that any offer of employment,

\footnotetext{
${ }^{66}$ See Clarke v. Atlantic Stevedoring Company; Mark Rothstein et al., Employment Law (1999).

${ }^{67} 408$ Mich 579 (1980).
} 
and acceptance thereof, does not constitute a binding contract of any length, and that such employment is terminable at the will of either party, subject to appropriate state and/or federal laws." ${ }^{68}$ The court held that the disclaimer was ineffective notwithstanding this express statement. The reason was that it "was not set off by a border or large print, was not capitalized, and was contained in a general welcoming section of the handbook." 69 The court's decision is hardly unique. In a number of cases, courts have said that disclaimers must be extremely clear. ${ }^{70}$

In addition, oral promises are frequently taken as binding, even if they have a degree of ambiguity. Thus, for example, in Toussaint v. Blue Cross, ${ }^{71}$ the court was confronted not only with a personnel manual but also with statements, from personnel officers to employees, that an employee would be able to continue to work "as long as I did my job," and or as long as "I was doing the job." 72 In an alternative holding, the court held that these statements were sufficient to justify an action for wrongful discharge, even if a specific term of years was not identified. Many cases find oral statements of this kind sufficient to create a right not to be discharged without cause. $^{73}$

These cases might be taken to reflect a new understanding of the reasonable expectations of employees, when presented with statements of this kind. Perhaps the modern cases reflect a belief that reasonable employees think that such statements give them job security. But the decisions might also be understood as a modest step in the direction suggested here: toward a waivable workers' right to job security, on information-forcing grounds. The idea is that the employer is in the best position to control the sorts of statements that are made to employees, and if ambiguous statements are made, the employer ought to correct the ambiguity, so as to negate any employee belief that a for cause arrangement has been created. The disclaimer cases fit this rationale particularly well. They are a kind of consumer protection measure, saying that if there is any chance that the employee will misunderstand what he has been promised, it is the employer's job to make an unambiguous correction.

It is a quite short step from these cases to a waivable employees' right to job security. The evidence suggests that ordinary employees, not told anything at all, are in the same position as employees told that their employers" "policy" is to retain them unless their performance is unsatisfactory. ${ }^{74}$ Employees typically believe that this is both policy and law. And if this is the understanding of most employees, employers should be required to make a correction. ${ }^{75}$

\section{Counterarguments and Anti-Waiver}

Thus far I have suggested that in the context of job security, a waivable employers' right might be preferred over a waivable workers' right, on the ground that the former is the market-

\footnotetext{
${ }^{68}$ McDonald v., Mobil Coal, 820 P. 2d 986, 987 (1991).

${ }^{69} \mathrm{Id}$.

${ }^{70}$ See, e.g., Jimenez v. Colorado Interstate, 690 F Supp 977 (D Wyo 1988).

${ }^{71} 408$ Mich 579 (1980).

${ }^{72}$ Id. at 610.

${ }^{73}$ See Rothstein et al., supra, at $\mathrm{xx}$; cases

${ }^{74}$ See Kim, supra note.

${ }^{75}$ See Isasachroff, supra note; Note, Reversing the Presumption of Employment At Will, 44 Vand L Rev 689, 710 (1991).
} 
mimicking rule, but that without good evidence on that question, a waivable workers' right seems better, because it is an information-forcing rule. I have also suggested that the default rule will indeed matter. But I have not discussed whether a nonwaivable workers' right would be best of all, and it is now time to discuss that possibility.

\section{A. Unequal Bargaining Power and Redistribution}

Many of those who challenge the at will system stress the possible inequality of bargaining power between employers and (many) employees, and suggest that a shift to a for cause system would produce a desirable form of redistribution to employees, above all to the most vulnerable workers. ${ }^{76}$ The reference to "inequality of bargaining power" must mean that many of the deals between employers and employees are harsh from the standpoint of the latter, and that the law should attempt to ensure a fairer arrangement. We should accept the claim of harshness, at least with respect to many of the relevant deals. Some employees have few good options, and in these circumstances, the best arrangement that they can get is often quite harsh, even unfair, in the sense that they are working very hard and receiving little in return. There is no reason whatsoever to think that the market wage has any special moral status. ${ }^{77}$

But the redistributive argument nonetheless stands on fragile ground - not because the existing distribution of entitlements and resources is good, but because blocking the exchange, through a nonwaivable right to job security, is an unlikely way to produce the desired redistribution. ${ }^{78}$ A nonwaivable workers' right to job security - and there is a general lesson for employment law here -- is an unreliable way of redistributing resources to workers. A "for cause" provision does not redistribute resources from employers to employees; it produces restructured deals, which may or may not benefit employees as a class. When mandatory for cause provisions are imposed, someone is going to have to pay for them. The burden may well fall on consumers or even workers themselves, in the form of lower wages, worse retirement benefits, or lower employment on balance (through, for example, more extended screening of job candidates, or refusals to take risks by employing people in the first instance). There can be no assurance that any redistribution to employees will make them better off as a class. ${ }^{79}$ In fact there is evidence that workers might lose in salary or other benefits most of, or as much as, they gain via the nonwaivable term (with the qualification that unionized workers appear to suffer from lower, or no, wage offsets). ${ }^{80}$

\footnotetext{
${ }^{76}$ See Clyde Summers, Individual Protection Against Unjust Dismissal, 62 Va L Rev 481 (1976); Lawrence Blades, Employment At Will vs. Individual Freedom, 67 Colum L Rev 1404 (1967).

${ }^{77}$ To some this will be a controversial claim and I will not defend it here.

${ }^{78}$ For an overview of the theoretical considerations, see Lawrence H. Summers, Some Simple Economics of Mandated Benefits, 79 Amer. Econ. Rev. (Papers \& Proceedings) 177 (1989). For a recent discussion with special reference to benefits limited to subgroups of workers, see Christine Jolls, Accommodation Mandates, Stan. L. Rev. (forthcoming 2001).

${ }^{79}$ Note the possibility that workers care not about absolute economic position but mostly or partly about relative economic position; if this is true, nonwaivable workers' rights might be justified on the ground that they provide a beneft, in the form of increased job security, while also keeping relative economic position constant. See Robert Frank, Choosing the Right Pond (1983); see also section VII below.

${ }^{80}$ See Jonathan Gruber, The Incidence of Mandated Maternity Benefits, 84 Am. Econ. Rev. 622 (1994), and Price Fishback and Shawn Kantor, Did Workers Pay for the Passage of Workers' Compensation Laws, 110 Q J Econ. 713 (1995) (finding substantial wage offsets): "Analysis of the effect of the introduction of workers' compensation on wages shows that in the coal and lumber industries, workers experienced substantial wage offsets. In the coal
} 
The redistributive argument for nonwaivable terms might be fortified with the suggestion that workers face a collective action problem that is best solved via law. John Stuart Mill outlined the argument long ago, suggesting that with respect to a reduction in hours worked, the limitation "will not be adopted unless the body of operatives bind themselves to one another to abide by it. . . . For however beneficial the observance of the regulation might be to the class collectively, the immediate interest of every individual would le in violating it; and the more numerous those were who adhered to the rule, the more would individuals gain by departing from it. . . . Assuming then that it really would be the interest of each to work only nine hours if he could be assured that all others would do the same, there might be no means of their attaining this object but by converting their supposed mutual agreement into an engagement under penalty, by consenting to have it enforced by law." 81

Mill's suggestion is sufficient to show that with respect to any particular contract term, workers who are currently employed at a firm might well do better with a nonwaivable legal constraint than without one. But as an argument that nonwaivable terms promote redistribution, two problems remain. First, and as noted, the compensation package might be adjusted to the detriment of workers; it is even possible that workers will lose in wages what they gain in reduced hours, and the resulting package might be worse from their point of view. ${ }^{82}$ Second, the result of the nonwaivable term might well be to increase unemployment, even if - indeed precisely because -- current workers are made better off. ${ }^{83}$ The increase in unemployment is a serious problem from the distributive point of view, especially because the people who are thrown into joblessness are likely to be among the least advantaged members of society.

These points do not demonstrate that nonwaivable terms cannot be justified from the standpoint of producing desirable redistribution. ${ }^{84}$ Perhaps the wage offset will be less than $100 \%$; in the unionized sector, for example, there appears to have been no wage offset as a result of workers' compensation legislation. ${ }^{85}$ Perhaps the adverse effect on unemployment will be low and justified in light of the benefits of the nonwaivable term for larger classes of people; perhaps the problem of increased unemployment can be taken care of through other means. My conclusion is not that nonwaivable terms are always indefensible on redistributive grounds. ${ }^{86}$ It is that the case for such terms, on those grounds, is fragile, and depends on highly uncertain empirical issues.

industry the offsets were large enough to cover not only the expected monetary value the benefits, but also the employers' costs of purchasing the insurance to provide those benefits." Id. at 736.

${ }^{81}$ J.S Mill, Principles of Political Economy 351(Jonathan Riley ed. 1994).

${ }^{82}$ See the evidence of substantial wage offsets for workers' compensation and parental leave, supra note. But note the relative position problem, taken up in section VII below.

${ }^{83}$ On the ambiguous evidence that labor unions increase compensation packages while also decreasing employment, see Freedman and Medoff, supra note, at 21, 43-60.

${ }^{84} \mathrm{See}$, Jolls, supra note (discussing the circumstances in which desirable redistribution will occur).

${ }^{85}$ See Fishback and Kantor, supra, at 734.

${ }^{86} \mathrm{It}$ is generally agreed that regulation via a nonwaivable term is inferior to regulation via a redistributive income tax. But it is possible that the choice is not between these two options, but between no redistribution at all and regulation via a nonwaivable term. 


\section{B. The Problem of Information, With Notes from Behavioral Economics}

A sensible reason to create nonwaivable workers' rights is to ensure that the employee is adequately informed. We have seen that shifting the entitlement to the worker, while maintaining freedom of contract, is a way of counteracting worker ignorance.$^{87}$ But this may not be sufficient. If workers are allocated the right, but asked to waive it, will they know what they are doing? This is an empirical question, and it lacks an obvious answer.

1. Intransigent ignorance. With respect to job security, there is evidence that workers will not believe that a waiver is effective even if they are asked to sign it. The most striking evidence here comes from Kim's study. One of Kim's questions asked employees to evaluate the effects of a personnel manual providing that the employer "reserves the right to discharge employees at any time, for any reason, with or without cause." ${ }^{88}$ In New York, California, and Missouri, this kind of provision eliminates any employer obligation. Nonetheless, in all three states about threequarters of respondents persisted in the belief that a pure cost-saving discharge would be unlawful notwithstanding the disclaimer. ${ }^{89}$

It would be possible to respond to such evidence by endorsing a mandatory for-cause regime. Perhaps employees simply cannot be adequately informed of an employer's decision to purchase the relevant entitlement. But if the costs of a mandatory regime are very high, this would seem an unfortunate conclusion. The best strategy might be to require extremely clear language so as to ensure that waivers are voluntary and knowing, as, for example, through strong verbs and specific language. ${ }^{90}$

2. Excessive optimism. People tend to be risk optimists. ${ }^{91}$ They believe that they are peculiarly immune from probabilistic harms faced by others. For example, $90 \%$ of drivers believe that they are safer than the average driver and less likely to be involved in a serious accident. ${ }^{92}$ Perhaps workers who waive their rights will believe, wrongly, that they are peculiarly immune from the risk to which they are subjecting themselves. If this is the case, waivers will be inadequately informed. It is not clear how to respond to this possibility. Perhaps the best remedy is not to be a ban on waiver, but efforts to inform employees in the clearest possible terms, so as to ensure that they are made aware that the risks are ones that they themselves will face.

\footnotetext{
${ }^{87}$ It is also possible to think that job security, like safety, is a public good, in the sense that it cannot be provided to one employee without simultaneously being provided to many; job security requires procedures to test the legitimacy of termination, and these procedures are a public good. See Paul Weiler, Governing the Workplace (1993). To keep the discussion from becoming unwieldy, I defer it until a treatment of the issue of safety. See below.

${ }^{88} 1999$ University of Illinois Law Review at 465.

${ }^{89} \mathrm{Id}$.

${ }^{90}$ Id. at 465 n. 63.

${ }^{91}$ See Shelley Taylor, Positive Illusions (1989); Christine Jolls, Behavioral Economic Analysis of Redistributive Legal Rules, in Behavioral Law and Economics 288, 290-92 (Cass R. Sunstein ed. 2000).

${ }^{92}$ See Shelley Taylor, Positive Illusions 10 (1989).
} 
3. Inadequate foresight. Signing contracts before the fact, workers may not have a good sense of what is in their long-term interest. ${ }^{93}$ They might be myopic or short-sighted. Recent evidence so suggests. ${ }^{94}$

As we have seen, the endowment effect means that those who have a benefit are likely to value it more than those who do not. Oddly, however, it appears that people do not anticipate the endowment effect. ${ }^{95}$ In simple studies, people did not see that they would value mundane goods, such as mugs, far more if they were initially allocated to them. Apparently people do not quite see how bad it will be to lose something once they have had. A possible conclusion is that workers will be in a poor position to decide whether or not to waive their rights, because they will not know, before the fact, how bad it would be to lose their jobs. ${ }^{96}$ If this is so, waiver might be banned in workers' own interests.

To some extent, this problem might be solved via a system of waivable workers' rights. In such a system, the presumptive right is with employees, not employers, and hence the endowment effect need not be imagined. On the other hand, it may be quite hard for employees, at the time of signing the agreement, to have a full appreciation of what it is that they may be losing. ${ }^{97}$ Workers may not sufficiently bargain to retain a legal right of some sort, simply because they may know not how important (for example) continuation in a particular job.

4. "Editing out." People sometimes "edit out" events that have very low probability, even if the ultimate impact of the event is quite large, partly because of simplified "decisional paths" used for choices having multiple attributes. ${ }^{98}$ The terms of employment contracts are numerous, and it is unlikely that most employees will be able to focus on more than a few of them. In fact protection against arbitrary discharge seems to be a low priority item for most employees, notwithstanding its potential importance..$^{99}$ There may be an analogy here with disaster insurance; people tend not to purchase disaster insurance (for floods and tornadoes, for example) even when the benefits of doing so clearly seem to exceed the costs. ${ }^{100}$

These various points hardly create a devastating argument on behalf of a system of nonwaivable employees' rights. They raise, first, a number of empirical questions about what is likely to be involved in waivers, and second, a number of normative questions about how to handle employee mistakes. Without further empirical information, the judgment about whether to allow waivers will have to depend on comparing (a) the likely costs of a nonwaivable rule

\footnotetext{
${ }^{93}$ Thus John Stuart Mill, no friend of government interference with freedom of contract, went so far as to suggest that an "exception to the doctrine that individuals are the best judges of their own interest, is when an individual attempts to decide irrevocably now, what will be best for his interest at some future and distant time. The presumption in favor of individual judgment is only legitimate, where the judgment s grounded on actual, and especially on present, personal experience; not when it is formed antecedently to experience, and not suffered to be reversed even after experience has condemned it." Mill, supra, at 345.

${ }^{94}$ See Bewley, supra note.

${ }^{95}$ See Loewenstein and Issacharoff, supra note.

${ }^{96}$ See Issacharoff, supra note.

${ }^{97}$ See Issacharoff, supra note.

${ }^{98}$ Isacharoff at 1801.

${ }^{99} \mathrm{Id}$.

${ }^{100}$ See Kunreuther, supra note.
} 
against (b) the likely costs of employee ignorance and mistake. If it is possible to design a nonwaivable rule with low costs of administration - as perhaps Montana has done ${ }^{101}-$ speculations about employee ignorance may well be sufficient to carry the day. If, on the other hand, a nonwaivable rule will create serious problems, the speculations should require stronger empirical support before they can be made decisive.

\section{Between Waivable and Nonwaivable: Constrained Waivers}

Even if the various objections to waiver are taken to have substantial force, it need not follow that waiver should be banned. A more flexible approach would be to allow waiver, but only under certain constraints, perhaps in the form of "floors" on what employees may be allowed to trade in return for waiving their rights. On this approach, the relevant right would be "commodified" in the sense that it could be traded on the market; but to protect employees against a failure of information, waivers would be constrained. It is easily possible to imagine intermediate solutions.

1. Procedural constraints. At one extreme, law could provide that a waiver is acceptable, but not simply when an employee has signed an agreement to waive. The waiver must be shown to be fully informed, perhaps because accompanied by clear language and a cooling-off period, in which the employee is permitted to reconsider. Consider this a procedural constraint on waivers. A legal constraint of this kind could be designed to furnish information, directly and also indirectly, by imposing requirements intended to signal the magnitude of the discussion. A procedural constraint on waiver could be minimal or much more than that.

The general idea has clear antecedents in current law. We have seen that under the common law as now understood, employer disclaimers must be extremely clear and conspicuous; explicit language is not enough. Under the Age Discrimination Act, a similar approach is taken to waivers of antidiscrimination rights. For rights and claims arising before execution of the waiver, the statute permits waiver so long as it is "knowing and voluntary." as an affirmative defense. To count as knowing and voluntary, the waiver must specifically refer "to rights or claims arising under" the Act; the employer must be advised in writing to consult with an attorney before executing the agreement; the employee must be given "at least 21 days within which to consider the agreement"; the agreement must provide that at least 7 days after the agreement has been executed, "the individual may revoke the agreement." ${ }^{103}$ Most of these provisions apply as well to waivers in settlement of charges filed with the EEOC. ${ }^{104}$ These provisions of the Age Discrimination in Employment Act can be taken as models of a procedurally constrained waiver. (Waivers may not apply to rights or claims that arise after the date the waiver is executed; here waiver is entirely blocked, ${ }^{105}$ an issue that I take up below.)

2. Substantive constraints. At another extreme, waiver might be deemed acceptable, but only at a price determined by government, not at a price determined by the market. Here there

\footnotetext{
${ }^{101}$ See note supra.

$102626(f)(1)$.

${ }^{103} 525(\mathrm{f})(1)$.

${ }^{104} 626(\mathrm{f})(2)$.

105 626(f)(1)@.
} 
is a substantive constraint on waivers. Substantive constraints, like procedural ones, might be minimal or much more than that.

This approach also has a place in contemporary employment law. An example is the Fair Labor Standards Act, which allows employees to waive their right not to work more than forty hours a week, but also at a governmentally determined premium ("time and a half"). ${ }^{106}$ Or consider the Model Employment Termination Act, which allows employers and employees to waive the right to for cause discharge, but only on the basis of an agreement by the employer to provide a severance agreement in the event of a discharge not based on poor job performance. ${ }^{107}$ The severance agreement consists of one month's salary for every year of employment; interestingly, it is therefore targeted to longevity of service, in a way that maps onto the employees' likely growing stake in their job.

For those who are skeptical of simple market waivers, these various approaches supply a model, in the form, not of a flat ban on waivers, but of a system of substantive constraints, designed to ensure that the employee is given something of definite value in return for waiver.

\section{How To Handle Job Security}

I have been attempting to work through issues of job security from a perspective informed by behavioral economics. The most important goal is to increase understanding of the underlying issues, not to recommend any particular reform. Nothing I have said suggests that courts should declare, today or tomorrow, that contracts are presumed to contain an implied term for job security. An obvious reason is that judicial activity of this kind would disrupt longstanding understandings on which both employers and employees have relied. To be sure, job security is an issue that has been resolved to a large degree by the common law. But when people have organized their relationships on the basis of one understanding, the presumption should be in favor of maintaining the status quo. Another problem is that courts cannot alone devise an important part of a sensible for cause system: a simple, low-cost mechanism for resolving disputes about whether cause exists. By encouraging arbitration, as Montana has done, ${ }^{108}$ a legislature can ensure that the consequence of any for cause agreement is not disastrous, for employers and employees alike. But a waivable workers' right could produce serious problems if unaccompanied by a system to ensure that disputes are handled inexpensively. Because a shift in the default rule would have a disruptive effect on workeremployer relations, it should not be imposed by the judiciary alone.

There are substantive concerns as well. A waivable right of this kind would impose nontrivial transactions costs for those who seek waiver, and these costs will have to be borne by someone, perhaps consumers and workers themselves. If workers would generally waive, what is the point? The best answer is that we do not know if workers would generally waive, and without knowing whether they would, the point is to test the market by ensuring that waivers are informed. But under certain assumptions, it would make sense to favor an at will background rule simply because of distrust of workers' failure to waive. Perhaps workers would be unwilling

\footnotetext{
${ }^{106} 29$ USC 207(f)

107 Section 4․

${ }^{108}$ See note supra.
} 
to sell their right to job security, even at a reasonable price. On this view, the endowment effect, combined with employee ignorance, would lead employees to demand an exceedingly high premium for waiver, and the consequence would be adverse effects on workers themselves. If workers would systematically overvalue job security, the at will rule finds support, rather than a challenge, from an understanding of human cognition. This is a plausible speculation but no more than that.

I conclude with two proposals. First, courts should build on existing law so as to take ambiguous terms as an occasion to require employers to negate any possible worker inference of job security. Second, state legislatures should experiment with a waivable workers' right. An approach of this sort would be more cautious and modest than the Montana solution, which appears not to have created serious problems. ${ }^{109}$

\section{Workers' Entitlements and the Problem of Waiver}

The analysis thus far might be applied to many areas of employment and labor law. I offer a large number of examples here, not to resolve any of them authoritatively, but to show the generality of this foregoing analysis of the question of entitlements in employment, and also to explore the attractiveness of waivable workers' rights in various settings.

There are, however, potential differences between the contract at will situation and other contexts in which the legal system might choose among waivable employers' rights, waivable workers' rights, nonwaivable workers' rights, and constrained waivers. To get a bit ahead of the story, these include (a) the existence of third party effects from some waivers, (b) the possibility that the reform in question is attempting to change norms and preferences, not to take them as given, and (c) the fact that some workplace benefits require employers to produce "local public goods," for which individual bargaining is unreliable.

\section{A. Occupational Safety and Health}

Under federal law, workers are given certain safeguards against hazardous and unsafe conditions in the workplace. ${ }^{110}$ But the relevant rights are not waivable. Should workers be allowed to make trades with their employers? Suppose that employees would willingly trade a certain level of safety in return for other benefits, such as cash, health care, or leisure time. Ought the law to authorize the trade?

In an essay in very much the same general spirit as this one, Susan Rose-Ackerman has suggested a mixed answer, involving a two-tiered approach to protection of workers. ${ }^{111}$ She proposes that the federal government should issue rules governing legal minima; these would not be waivable, because they would reflect levels of safety that reasonable workers would not wish to relinquish. At the same time, Rose-Ackerman suggests that OSHA should issue "benchmark

\footnotetext{
${ }^{109}$ See Bruce Fein, Jr., unpublished manuscript; Matt Schmidt, unpublished manuscript.

${ }^{110}$ USC

${ }^{111}$ See Susan Rose-Ackerman, Progressive Law and Economics, 98 Yale LJ 341, 358-60 (1988).
} 
standards," more protective than the legal minima, that workers could waive for compensation. ${ }^{112}$ The waivers might be agreed upon individually or collectively, via unions or other representative structures.

The proposal has many virtues. By calling for certain nonwaivable minima for truly dangerous conditions, it responds to potential problems with inadequately informed waivers. At the same time, the proposal grants workers a presumptive right to extra protection; the endowment effect should ensure that workers do not relinquish that right for little or nothing. To those who fear that workers will waive their right to "safety" for too little, it might be responded that safety cannot be determined through some "off-on" switch. The question is the appropriate degree of safety, and informed people can sensibly resolve that question in different ways, trading degrees of safety in return for other goods. A special point on behalf of Rose-Ackerman's proposal is that expensive safety regulation can be harmful not only to workers' incomes but also to workers' health. ${ }^{113}$ To the extent that such regulation decreases wages, and increases unemployment, it can produce mortality and morbidity increases as well. The central question is whether cognitive and motivational problems will lead workers to waive their rights for too little. If the set of nonwaivable minima is adequate, and if the initial grant of the right goes to workers, there is good reason to experiment with a two-tiered approach of this kind.

\section{B. Age Discrimination}

The Age Discrimination in Employment Act (ADEA) forbids employers from discriminating against anyone who is over forty years of age; it also bans practices of mandatory retirement. Through these provisions, it creates an obvious incentive for employers to devise some kind of "retirement package" by which older workers might be encouraged to retire. Although such packages might be deemed a form of age discrimination, it is easy to imagine circumstances in which such a package would be in the mutual interest of employer and employee. Suppose, for example, that the employee is generally interested in retiring in any case, but would not do so without some kind of financial cushion. Suppose too that the employer wants to replace the older worker with a younger one, believing that the younger worker will produce substantial productivity gains, at least in the long term.

Incentives for early retirement seem a natural and mutually beneficial solution, and in fact they were a widespread response to the ADEA. ${ }^{114}$ To be worthwhile, employers would naturally seek not only retirement, but also a promise not to sue for violations of the ADEA. Initially, courts reacted with some ambivalence to the resulting plans. ${ }^{115}$ Generally they upheld workers' waivers of statutory rights, but required that any waiver be "knowing and voluntary." Confusion about the meaning of this requirement helped spur Congress to enact the Older Workers Benefit Protection Act, ${ }^{116}$ which, as discussed above, authorizes knowing and voluntary

\footnotetext{
${ }^{112}$ Note that it is possible to urge that any waiver should be collective rather than individual; this issue is taken up below.

${ }^{113}$ See Symposium, J. Risk and Uncertainty; Cass R. Sunstein, Health-Health Tradeoffs, in Free Markets and Social Justice (1997).

${ }^{114}$ See Linda Messinger, Voluntary Acceptance of Early Retirement Offers, 20 Ariz St. LJ 79 (1988).

${ }^{115}$ See Blistein v. St. John's, 74 F3d 1459 (4 ${ }^{\text {th }}$ Cir 1996); Wamsley v. Champlin, 11 F3d 534 (5 ${ }^{\text {th }}$ Cir 1993).

11629 USC 626(f).,
} 
waivers. Because OWBRA does not permit employees to waive rights that postdate the execution of the waiver, it does not quite amount to the kind of waivable workers' right that I have been discussing here. Instead it permits something like a settlement of a preexisting claim; the settlement operates as a waiver. The question therefore becomes why employers are not permitted to ask for waivers before the unlawful activity occurs. Why shouldn't employers be allowed to obtain a waiver of a right to bring suit for alleged age discrimination, if employees are willing to agree?

Christine Jolls has suggested that prospective waivers should indeed be allowed. ${ }^{117}$ On her view, the ADEA has, as one of its central purposes, the prevention of opportunistic discharges, which occur when employers discharge employees in late career, in violation of an implicit promise to provide continued benefits. The statute therefore has a "hands tying" rationale that ensures enforcement of these contracts in spite of employers' incentives to act opportunistically. This is an efficiency argument for the ADEA; but there is a parallel efficiency case for allowing the workers' right to be waivable. On Jolls' view, "the basic efficiency argument in favor of prospective waivers is that they allow parties for whom age-based wages are not desirable - or at least not sufficiently desirable to warrant the costs of imposing legal liability for cost-based decisions about older workers - to avoid unnecessary and costly regulation of their private affairs."

There is, however, a potential problem here: myopic behavior by workers. As Jolls acknowledges, young workers are in a poor position to assess the harms possibly to be incurred by their future selves several decades hence. ${ }^{119}$ The possibility of myopia may be a sufficient ground to bar waiver. In principle, it does seem unlikely that waivers of the right to be free from age discrimination would be adequately informed. If waivers are nonetheless to be permitted - as I think they should be - it is because freedom from age discrimination is unlikely greatly to benefit workers, and hence the resulting deals are unlikely to hurt workers.

\section{Vacation, Leave Time, and Health Care}

A great deal of attention has recently been given to various proposals to improve workers' lives through longer vacations, extended leave time, and health care. Critics have argued that statutory mandates would provide a kind of rigid, "one-size-fits-all" approach to diverse workplaces, and that the best approach is to allow people to bargain as they wish. It should now be clear that the criticism is quite reasonable. If employees would like to sacrifice vacation and leave time, or health care benefits, in return for other elements of a compensation package, why should they not be permitted to do so?

The contract at will situation has a special feature not present here: Empirical evidence that workers believe that they already have the right in question. We lack evidence that showing that workers believe that employers are obliged to provide them with vacation and leave time or health care. Perhaps they do. Even if they do not, there are good reasons to ensure that if workers are not going to have these rights, they are made expressly aware that this is something that they

\footnotetext{
${ }^{117} \mathrm{Id}$.

${ }^{118}$ Christine Jolls, Hands-Tying and the Age Discrimination in Employment Act, 74 Tex L. Rev. 1813, 1845 (1994).

${ }^{119} \mathrm{Id}$.
} 
will not have. The natural proposal is that workers have waivable rights to a certain level of vacation and leave time, along with health care protection - and that employers are able to purchase these rights for a fee.

It is possible to respond that workers will relinquish these rights too cheaply or that collective action problems will induce workers to act against their best interests. The response is generally weak, for reasons discussed above. But workers might lack the information to give fully knowing waivers, and a form of myopia might produce impulsive action. As in the context of occupational safety and health, the best response to this concern would be to produce nonwaivable minima along with procedural or substantive constraints on the waiver of rights that exceed those minima. What I am generally envisioning, in short, is a two-tiered system, in which workers are providing with a floor below which no workplace may go, together with a set of waivable rights that respond to the legitimate claim that one size does not fit all. Of course it would be necessary to say a great deal more in order to grapple with the details.

\section{Parental Leave}

In 1991, the United States adopted, for the first time, a statute requiring employers to provide parental leave. ${ }^{120}$ The Family and Medical Leave Act requires employers to allow employees up to 12 total weeks of leave during any 12 month period, if the reason for the leave is to care for a new-born child, to care for a spouse, son, daughter or parent with a serious health problem, or because of a serious health problem of the employee's own. ${ }^{121}$ Employers are not required to allow employees to allow employees to continue to work at a reduced rate; nor are they required to pay employees during the time off. The basic idea is that an employee will not lose her job if she takes leave for one of the stated reasons.

The most notable feature of this legislation is that it transforms a waivable employers' right into a nonwaivable workers' right. Is the legislation desirable? It is tempting to think that it is, because it gives employees an important right that they would otherwise deny in many or most cases. But this is no simple transfer of resources for employers to employees, and an obvious question has to do with who really bears the costs of parental leave legislation. There is good evidence that those who bear the costs are the same as those who receive the benefits that parental leave legislation results in a proportional wage reduction for its beneficiaries, mostly women. If this is the case, is the statute undesirable for that reason? On one view, it certainly is; the government has simply forced workers to receive in leave time what they would otherwise receive in income, and the fact that they chose the latter, not the former, suggests that the latter is what is in their best interests.

But by now it should be clear that this argument is not decisive. ${ }^{122}$ Workers may be myopic in failing to seek parental leave protections, especially in light of the fact that before having a child, it is hard to have a full and vivid sense of the demands that arise after the child is born. For many workers, there may be no self-conscious thought about parental leave at all; this may be "edited out" at the time that employment is sought. As in the context of the contract at

\footnotetext{
12029 USC 2601.

12129 USC 102.

${ }^{122}$ For an illuminating treatment of some of the complexities here, see Jolls, Accommodation Mandates, supra note.
} 
will, both employers and employees may face a signaling problem. Employers who offer parental leave may find themselves attracting a disproportionate number of workers who want to take such leave; employees who ask about leave policies in advance may be signaling that they are not entirely committed to the workforce. Indeed, workers may face a norm against parental leave, and they may not even know that this norm is something that it is possible to challenge. In any case parental leave policies can be defended, not principally as protecting workers, but as protecting children and others for whom workers would like to care. If there are third-party effects, the case for an inalienable right is greatly strengthened.

At first glance, these considerations would seem to be reasons for disallowing waivers. But they are not decisive. If parental wages fall as a result of parental leave legislation, children will be correspondingly hurt. In the general run of cases, there is little reason to think that parents will not consider the well-being of their children in deciding whether and how much leave time to take. Whether workers are in a poor position to make that balance in advance cannot be decided a priori. A real problem is that in initial bargaining, workers are unlikely to be thinking about considering parental leave when they first take the job. ${ }^{123}$ And it would be possible to remedy this problem by giving employees the relevant right, and by allowing them to trade it if and only if the employers makes the trade worth their while. In these circumstances it would seem to make sense to consider a two-tiered system here as well, combining statutory minima with a more ample set of waivable rights.

\section{E. Workers' Compensation}

All states now provide workers' compensation programs. Moreover, the right to benefit from such programs is not waivable. Workers enter the employment relationship with assurance that in the event of accident, they will receive appropriate compensation. Workers' compensation programs do not merely have ex post consequences. They also have substantial incentive effects, leading employers to reduce accidents and injuries. Indeed, there is reason to think that workers' compensation programs are far more effective than OSHA in improving workplace safety. ${ }^{124}$

By itself, however, these points do not justify making workers' compensation programs nonwaivable. As in the context of parental leave legislation, there is good evidence that that workers' wages are cut correspondingly; what they receive from the program, in the event that they need it, is what they lose in wages. In this circumstances, why shouldn't workers be able to waive the relevant rights? If they did, they would be self-insurers, and self-insurance, so long as it is genuinely voluntary, is not an obviously implausible model for workplace injuries.

There are some familiar answers here. Workers may lack the information that would make a waiver sufficiently informed, perhaps because of myopia, excessive optimism, or dissonance reduction. But there is an independent issue. Workers who do not wish to waive their rights may face a collective action problem, and this problem may well justify a nonwaivable workers' right. More particularly, there is a distinctive free rider problem in this context. To see this, return to the fact that the consequence of workers' compensation programs is to lead employers to increase safety in the workplace. The increases often happen because employers

\footnotetext{
${ }^{123}$ Compare the discussion of severance benefits in Bewley, supra note.

${ }^{124}$ See W. Kip Viscusi, Reforming Products Liability 178 (1991).
} 
introduce capital improvements designed to reduce deaths and injuries. To the extent that these will be made in any case, employees who waive their rights for a fee will receive many of the protections of the program without paying for it. It is here that there is a problem. If safety is a local private good - something that, when provided to some, will also be provided to all rational individual choices, by workers, are likely to lead to a large number of waivers, and hence a failure to create incentives to increase safety. This, then, is an area where the argument for creating a nonwaivable workers' right is especially strong.

\section{F. Unionization: Company Unions, Ordinary Unions}

What of the right to unionize itself? Should that right be waivable? By whom? These issues are best approached by dividing the inquiry into three issues: individual waivers of the right to unionize; appropriate default rules for union status; and collective waivers of the right not to be faced with "company-dominated unions."

1. Nonwaivable individual employee rights. The rights guaranteed by the Wagner Act, the foundation of modern labor law, are not waivable by individual employees. Employers may not "buy" the right to fire employees who join unions as through, for example the "yellow dog" contract. The rights to join a union, to strike, and to engage in activity for mutual and protection are not subject to waiver. Why does the statute make this choice, rather than creating a system of waivable employees' rights?

There is no obvious answer. The best justification would rely on some combination of the reasons described above, involving informational, cognitive, and motivational problems. Perhaps many workers would not know what they were waiving, especially in light of the possibility that the potential benefits of unionization would not be readily apparent at the time the waiver was requested. Perhaps both employers and individual workers would face a signaling problem, akin to that which could arise if, in an at will regime, an employer emphasizes that it will provide job security (and thus attracts marginal workers), and an employee requests the same (and thus signals a realistic risk that the employer will want to fire him).

2. Unions at all? The current presumption against. This system of nonwaivable workers' rights coexists with what is, from the standpoint of the real-world status of unions, probably even more important: a basic background of a crucial waivable employers' rights: no collective representative is in place until employees have affirmatively voted for it. The ordinary assumption of the workplace, and hence the default rule, is nonunion. The situation that workers face is one in which organization must be sought, through the processes of union election. Note that nothing is inevitable or natural about this situation. On the contrary, this "tilt has its roots in the common law background ... the tacit legal assumption that the 'natural' state for a workplace is nonunion, with management exercising on behalf of the shareholder-owners the prerogatives of property and contract law to establish the firm's terms and conditions of employment." ${ }^{125}$ It would be easily possible to imagine a different regime, in which workers are presumed to favor collective organization, but in which they are permitted to vote otherwise. If

\footnotetext{
${ }^{125}$ Paul Weiler, Governing the Workplace 228 (1992).
} 
union representation is thought to have significant advantages, a system of this sort might well be preferred.

Many variations are possible. On one approach, workers would start employment with a presumption in favor of collective organization. A vote would be help to choose the particular form of that organization (including the particular union that would represent workers); at the same time, employees could be asked to reject the option if collective organization if they could be convinced that this is in their best interests. An advantage of this approach is that it could help overcome the effects of management tactics, many of them unlawful, to help overcome unionization. ${ }^{126}$ Another advantage is that this approach would work like an information-forcing default rule. If we are unsure whether failures of unionization stem from worker preferences or from employer pressure, a presumption in favor of collective organization would help untangle that issue. And to the extent that such organization confers benefits on workers without imposing correlative costs, ${ }^{127}$ there is much to be said for enlisting the endowment effect on its behalf. If, on the other hand, collective organization is thought to produce few real benefits for organized workers, and at the same time to increase both prices and unemployment, the existing default rule would stand on firm ground. What is most important is to see that the default rule represents a choice among a range of options and that it is likely to have extremely important effects; any such rule has to be defended against reasonable alternatives.

3. Company unions. Some of the most important and interesting issues in contemporary employment law arise as a result of the statutory ban on employer-sponsored workers' organizations. ${ }^{128}$ Employers are not allowed to create labor organizations, even if employees would be satisfied with them - apparently on the theory that employer-sponsored labor organizations cannot be trusted to protect employee interests. ${ }^{129}$ The theory seems to be that the employer should be on only one side not of the negotiating table, not on both sides. Thus Senator Wagner emphasized the coercion and deception involved in the use of company dominated unions, with the suggestion that such "sham" organizations were actually served the employer's interests, not that of workers. Hence the statutory prohibition was (and is) defended with reference to a fear of employer coercion, a belief that employees lack the information to make ex ante waivers, a risk of deceptive practice on the part of employers, and a perception that workers' preferences, in this context, may be adaptive to an unjust status quo.

In theory, these objections may have made sense in the 1930s, when company unions were primary tools in union avoidance, and were commonly used as part of a package of unionbusting tactics. But in the last two decades, circumstances have changed in two important ways. ${ }^{130}$ First, private sector unions have dramatically declined, and hence the real choice is not between unions and company-supported substitutes, but between no union and a companysupported substitute. It is hardly clear that no organization at all is best for workers. Second,

\footnotetext{
${ }^{126}$ See id.

${ }^{127}$ This is the theme of Freedman and Medoff, supra note.

${ }^{128}$ See 8(a)(2).

${ }^{129}$ For general discussion is Samuel Estreicher, Employee Involvement and the Company Union Prohibition, 69 NYU L Rev 101 (1994); Mark Barenburg, Democracy and Domination in the Law of Workplace Cooperation, 94 Colum L Rev 753 (1994).

${ }^{130}$ I borrow here from Estreicher, supra note.
} 
there has been a sharp decline in "Taylorist" conceptions of the workplace, which posit a sharp split between "brainwork" and the highly mechanical work of ordinary laborers. There is a great deal of new interest, on the part of employers themselves, in finding ways to increase the role of employees in designing more efficient workplaces, partly because this step increases worker satisfaction, partly because it appears to have desirable effects on production. The consequence of these two developments has been to impose sharp pressure on the prohibition on employeesponsored unions.

Suppose, for example, that an employer wants to create some kind of employees' organization to improve efficiency, safety, and working conditions. Under current law, this step is likely forbidden. ${ }^{131}$ The relevant right cannot be waived by workers acting individually or even collectively. But suppose that workers have thought long and hard about the issue, and have decided that they would do better with a company unions than without collective representation and with an ordinary union. The conventional response here is that the employees' judgment to this effect cannot be trusted, because the result of a company union is to place the employer on both sides of the bargaining table. In this view, the ban on company unions is designed to ensure against a kind of deceptive packaging - the appearance without the reality of collective representation - and at the same time to counteract the risk that workers' preferences will adapt to an unjust status quo. And if it were correct to say that without company unions, most workers would be faced with a choice between well-functioning unions and an absence of collective representation, this argument might be convincing. But the truth is that for a variety of reasons, unions are not a likely option for most workers - and also that for many workers, some kind of employee participation plan seems highly attractive, a source of genuine improvements in workers' well-being. ${ }^{132}$ The conclusion is that with at least with procedural constraints designed to ensure real freedom of choice, workers should be allowed to waive the apparent protections of the ban on company unions, at least if they do so collectively.

\section{Nonwaivable Workers' Rights}

In this section, I generalize from this discussion to identify some grounds for disallowing waiver. The central cases involve third-party effects, inadequate information, and efforts to change norms and preferences, which involve third-party effects of a distinctive kind.

\section{A. Third Party Effects}

Most obviously, a nonwaivable background rule makes most sense when there are thirdparty effects. There are many examples. As we will see, unions are not allowed to waive workers' rights to distribute work-related materials, partly because there is no identity of interests between the waiving union and the workers whose rights have been waived. The problem is that the waiver has effects on third parties, that is, workers with interests distinct from those of the union.

\footnotetext{
${ }^{131}$ See Electromation, 309 NLRB 990 (1992), enforced, 35 F.3d 1148 ( $7^{\text {th }}$ Cir. 1994)

${ }^{132}$ See G.W. L. Rev.
} 
In a series of common law cases, moreover, courts have created "public policy" exceptions to the at will rule. The core cases involve situations in which an employer discharges an employee for refusing to commit a crime (perjury, price fixing) on the employer's behalf. ${ }^{133}$ In other cases, courts have disallowed discharges when the employer is punishing employees for cooperating with the authorities with respect to possible illegality at the company. ${ }^{134}$ The defining theme is that employers may not discharge employees if the consequence is to impose harms on outsiders to the contractual relationship. ${ }^{135}$ It should be obvious that waivers are unacceptable in these circumstances. The waiver is invalid not to protect workers, but to ensure that others are not adversely affected. For the most part this category of cases is reasonably straightforward, and hence it is not necessary to discuss it in detail here.

\section{B. Inadequate Information}

In some cases, waivers will be inadequately informed. We have seen that this is a key reason that the law is more hospitable to union waivers than to individual waivers; unions are in a far better position to know what they are doing. Individual waivers may be inadequately informed for a large numbers of reasons, including excessive optimism, dissonance reduction, "editing out," and myopia.

A great deal of empirical research is necessary to see the extent of the problem. For the moment, the best approach is to block exchanges that most reasonable people would be unlikely to waive, ${ }^{136}$ but otherwise to allow waiver unless there is a particular reason for confidence that workers are giving up too much for too little. When there appears to be a serious risk to this effect, it might be best, not to block waiver entirely, but to impose procedural or substantive limits on acceptable waivers. Requirements of full disclosure, along with a "cooling off" period, might be a minimal way to proceed.

\section{Norm and Preference Change}

Now let us turn to some of the most difficult cases for waiver, involving what are perhaps best treated as subtle third-party effects.

1. Waiver: the basic case. Suppose that an employer is averse to the threat of race or sex discrimination suits. Seeking to reach a mutually advantageous solution, he asks his employees to sign an agreement, waiving their rights to bring suit for race or sex discrimination. The employer adds that he believes that discrimination is wrong and that he does not plan to discriminate. He is willing to make a premium for a waiver, not in order to discriminate, but to insulate himself from frivolous or trumped-up lawsuits. Suppose too that a nontrivial number of employees are willing to waive their rights, because they believe that this is otherwise a good place to work, because the premium is not trivial, and because they are willing to take their chances on the matter of race and sex discrimination. Let us assume, plausibly, that if employees are presumed to have the relevant entitlement, requests for waivers will be relatively rare, partly

\footnotetext{
${ }^{133}$ See Petermann.

${ }^{134}$ Palmeteer.

${ }^{135}$ Se Schwab, supra note.

${ }^{136}$ See Rose-Ackerman, supra note.
} 
because of the kind of signal given by such requests. Nonetheless, it is highly likely that some waiver requests would be made if they were seen as valid. Note in this regard that there is evidence that some of the discrimination laws do have an adverse effect on hiring members of the protected class, precisely because of a fear of a lawsuit; an employee in that class represents a lawsuit waiting to happen. ${ }^{137}$ Perhaps some of the disemployment effect could be removed with waivers. Should these waivers be upheld?

It might be tempting to see, in the employer's proposal, a kind of coercive offer: An employee is asked to waive his rights in return for a job, and she may seem to have "no choice" but to waive. On this view, the law should provide protection, and enhance freedom, by banning the coercive deal. But this account is much too simple. In these cases, the employee is not in a position of having "no choice"; the question is whether the offer is worthwhile for the employee in light of the options, perhaps most of them bad, that are available. Unless there is an informational problem of some kind, the fact that the employee accepts the deal is strong evidence that it is.

It is also possible to think that for some classes of workers, the sheer number of job applicants, and the relatively small number of jobs, will mean that employees will be "forced" to waive; those who do not waive will not end up with jobs. This is certainly imaginable. But in a market that is so unfavorable to workers, all employment terms will be pushed in unfavorable directions, including wages. Unless there is some kind of information problem, employees stand to gain if they can waive the right to be free from discrimination, because those who waive that right will (by hypothesis) gain more than they lose. The best solution, in a market with this degree of harshness for employees, is to improve the background conditions faced by those workers, not to block the best available deal.

2. Third party effects? Thus far, at least, it seems as if discrimination rights should be fully be waivable. But might individual waivers have adverse effects on other workers? Begin with the context of sexual harassment, where it is easy to imagine that they would. If one woman waive her right, and is subject to harassment, other women may well be harmed; the effect will not be easy to cabin. At least this is so if the waiver and the harassment lead would-be harassers to believe that harassment is not entirely objectionable or unacceptable, or that reasonable women are willing to subject themselves to a risk of it for a wage premium.

The example is easily generalized to the case of sex and race discrimination in general. An African-American who is willing to waive the right to be free from racially-motivated adverse employment action might well be affecting other African-Americans, by signaling the legitimacy of discrimination, and by indicating that discrimination is merely a "cost," to be purchased and sold like other goods on the market. If discrimination is so regarded, there may well be more of it than if the signal is different - as, for example, where a flat ban suggests that discrimination is illicit, the sort of practice to be eliminated, rather than to find some optimal point. $^{138}$

\footnotetext{
${ }^{137}$ See Richard A. Posner, Aging and Old Age (1997).

${ }^{138}$ Compare the area of pollution. Some people have objected to emissions trading - a kind of waivable nonpollution right - on the same ground. See Steven Kelman, What Price Incentives? (1981) The best response is that there is an
} 
3. Norm and preference change. This claim suggests several possibilities. Some antidiscrimination law is an attempt to produce norm change. The point of the law is to alter prevailing norms, and if rights are waivable, that enterprise might be defeated. If workers are living in accordance with a norm that they abhor but that they wish to change, they are unlikely to be able to accomplish the change on their own. By its very nature norm change requires collective action. The waiver is forbidden in order to ensure that certain norms are delegitimated. A closely related possibility is that the purpose of the relevant right is to produce preference change. If preferences are not being taken as given, but are being treated as endogenous and flexible, an argument for preventing waiver might be defended as a method for ensuring that preferences are in fact changed.

With respect to the validity of discrimination waivers, these arguments are not decisive in the abstract. In a period in which race and sex discrimination are widely stigmatized, it is reasonable to believe that permitting waivers would have few significant effects on workers not parties to the deal, or at the least, that waivers would not have a material effect in entrenching objectionable norms and preferences. If an employer asks employees to waiver the right to be free from race or sex discrimination, it is signaling that it is a possible discriminator, and that is not the most attractive signal to send out to prospective employees. On the other hand, some employees - white and male? - might welcome that signal, and in these circumstances the ban on waiver is understandable as an effort to prevent inevitable effects on third parties, who are likely to be affected by the legitimization of the underlying practice. When the law is engaged in a self-conscious effort at changing norms and preferences, allowing waivers is too likely to defeat the enterprise at hand. ${ }^{139}$

\section{A Brief Note on Union Waivers}

The discussion thus far has involved individual waivers; but a frequent issue in employment law is whether labor unions are themselves entitled to waive workers' rights. The general answer is that union waivers are legally acceptable, ${ }^{140}$ though in some contexts there is a self-conscious effort to ensure that any waiver is knowing and voluntary, in a kind of procedural constraint on enforceable waivers. ${ }^{141}$ Is it possible to explain the law's receptivity to union waivers?

There are two points here, sharply distinguishing union waivers from individual waivers. First, informational problems are highly likely to have been overcome in the union setting. When a union is waiving, it would be surprising, in the ordinary case, if it did so without really knowing what it is doing. In all probability, the problem of myopia will also have been reduced; note in this regard that unions are not solely concerned with wages, and that various fringe

optimal level of pollution, and polluting activity - so long as it is part of a legitimate business, and not an intentional tort -- is not the kind of thing that it is appropriate to delegitimate.

${ }^{139}$ On the other hand, it is clear that victims of discrimination can settle, and at least if they do not "tender back" the money, a financial settlement appears to preclude a suit for reinstatement.Fleming v. US Postal Service, 27 F3d 259

( $7^{\text {th }}$ Cir 1994); see also Rangel v. El Paso, 996b F Supp 1093 (D NM 1998).

${ }^{140}$ See IAM v. United, 534 F2d 422 (2d Cir 1975) (upholding waiver of reinstatement rights after settlement of a strike); Metropolitan Edison v. NLRb, 460 US 693 1983).

${ }^{141}$ Se Metropolitan Edison v. NLRB, 460 US 693 (1983). 
benefits, likely to be favored by those interested in the long term, are a special focus of union bargaining. ${ }^{142}$ Second, unions overcome the collective action problem faced by individual workers, and this point lessens the danger that employers will be able to "force" individual workers to waive by ensuring that they compete to their collective detriment. It should be no wonder that serious concerns about union waivers seem to arise only when the union has a conflict of interest, and hence is not in a position to be a good representative of workers. Thus unions are permitted, in the most noteworthy case, to waive workers' right to strike. ${ }^{143}$ With respect to the rights guaranteed by the National Labor Relations Act, the situation is largely one of waivable workers' rights-with the rights being waivable collectively only, and emphatically not individually.

Consider in this regard cases in which the union cannot be trusted to be a fair representative of workers' interested, exemplified by NLRB v. Magnovox Co. of Tennessee. ${ }^{144}$ In that case, the union agreed to a collective bargaining agreement that banned employees from distributing literature on any of the employer's property, including nonworking areas during nonworking time. It is clear that this rule would violate the law if imposed unilaterally by the employer; but the union had agreed to it. Nonetheless, the Supreme Court held that the waiver was not binding, for a collective bargaining agreement could not eliminate these rights. The Court said that waiver would not be permitted "where the rights of the employees to exercise their choice of a bargaining representative is involved - whether to have no bargaining representative, or to retain the present one, or to obtain a new one. The key problem was one of agency - with respect to continuing debates about self-representation, the union could not be trusted to be the faithful agent of workers. Here is a distinctive reason to disallow union waivers. Magnavox is followed by a series of cases that are generally receptive to waivers by unions, but not when the waiving union is likely to have divergent interests from those of the individuals whose rights are waived.

One final wrinkle is important here. In many contexts, union waivers must be explicit and unambiguous. A general "no-strike" clause will not be taken to bar an unfair labor practice strike, ${ }^{145}$ and it will also not be taken to create an affirmative obligation on union leaders, to avert strikes on pain of discipline or discharge. ${ }^{146}$ If employers are going to obtain rights beyond those minimally contained in a no strike pledge, they must do so explicitly. Here is a procedural constraint on the waiver of workers' rights; and it has proved crucial in the cases.

\section{The Problem of Relative Position}

The discussion thus far has neglected an important and highly relevant point from behavioral economics. I do not discuss it in detail here, because it raises many complexities and depends on empirical issues on which unambiguous evidence is lacking. But because the point is significant, and has been neglected in the context of employment and labor law, it requires some discussion.

\footnotetext{
${ }^{142}$ See Richard Freedom and James Medoff, What Do Unions Do? (1984).

${ }^{143}$ See Mastro Plastics Corp. v. NLRB, 350 US 270, 281 (1956).

${ }^{144} 415$ US 322 (1974).

${ }^{145}$ Mastro Plastics Corp. v. NLRB, 350 US 270, 281 (1956).

${ }^{146}$ Metropolitan Edison Co. v. NLRB, 460 US693 (1983).
} 


\section{A. Relative Position and the Frame of Reference}

Let us acknowledge the that the cost of workers' rights, when they are not waived, might be borne in whole or in part by workers, in the sense that the legal grant of a right, to workers, will result in a lower paycheck. Is the argument against the relevant right therefore established, on the ground that workers will be net losers? We have seen that one problem with an affirmative answer is that workers might not be net losers. But a more fundamental problem is that with respect to income, what workers seem to care about is relative economic position rather than absolute economic position. ${ }^{147}$ In other words, what matters to workers is partly how they compare to others, not how much money they are making in the abstract; and if all workers lose the same amount, each worker will lose very little, because relative position will not be affected. If what workers care about is relative position, nonwaivable rights might, in principle, make workers better off on the dimension along which they are helped (by giving them something important) while also not making them worse off along the dimension along which they are apparently helped (by decreasing their income while also decreasing that of everyone else).

Relative position is found by comparing the worker's income with that of (salient) other workers; absolute position by looking simply at the number of dollars that the worker makes. The question is whether workers are significantly worse off in a system in which all (salient) workers lose, say, .5\% of their salary; if this loss has no significant adverse effect, than any initiative that produces that loss will not, by virtue of that consequence, harm workers at all. And if this is so, it is because income is, above a certain floor, a positional good, that is, a good whose value depends on comparison with the holdings of others. The noteworthy possibility here is that legal initiatives might, in theory, produce real gains of one or another kind (for example, leisure time, health care, job security, which are, by hypothesis, nonpositional goods), without producing real losses (because the only loss is to relative position in terms of income).

There is considerable evidence that relative position is in fact what people care about, at least with respect to income. ${ }^{148}$ Many people would prefer to work in a place where they earned (say) $\$ 60,000$ and the average worker earns $\$ 50,000$, to working in place where they earn (say) $\$ 70,000$ and the average worker earns $\$ 90,000$. This preference holds where everything else is equal, that is, where the cost of living is the same in the two places. Why are people prepared to sacrifice income to ensure certain place in the hierarchy? Undoubtedly envy and status-seeking play a large role. Some people would like to have a high status and are willing to lose money to ensure that they do. Perhaps more people would like not to have a low status and are willing to lose absolute income in order to ensure that they do. But the most important point is more fundamental. The economic position of other people sets the "frame of reference" within which we evaluate various goods. If you now had the same computer that you used ten years ago, you would likely be dissatisfied and frustrated, simply because the frame of reference for evaluation of the computer has changed so dramatically. But if everyone had the same computers that they had ten years ago, your decade-old computer would not seem so bad, indeed it might not seem

\footnotetext{
${ }^{147}$ See Robert Frank, Choosing the Right Pond (1985).

${ }^{148}$ See id; see also Robert Frank and Cass R. Sunstein, Cost-Benefit Analysis and Relative Position, U Chi L Rev (forthcoming 2001).
} 
bad at all. And if everyone had the same computer that will be in use ten years from now, your current computer might seem very slow and inefficient.

What is true for computers is no less true for a vast array of goods and services, including cars, radios, televisions, homes, and even artistic and literary work. People care about relative position not only because they care about their status, but also because they are aware that the frame of reference for evaluation is set not individually but socially, and indeed that this is inevitably the case.

\section{B. Mandatory Terms and Relative Position}

For the moment let us simply assume that relative rather than absolute economic position is what most workers care about - that worker well-being would not be decreased by (say) a decrease in annual wages of $\$ 25, \$ 50$, or $\$ 100$, so long as all workers face the same decrease. In that event, some nonwaivable terms, such as a right to job security, might be justified on the following ground: The consequence of the new term is to decrease absolute income but to hold relative income constant. From this shift, there is little or no welfare loss to workers. At the same time, workers receive a substantial benefit, e.g., job security, vacation time, or health care. As far as the worker is concerned, the substantial benefit is given essentially for free, because relative position is held constant. If relative position is in fact what workers care about, this appears to be a powerful argument for a wide range of nonwaivable workers' rights.

\section{Difficulties}

I believe that this argument is largely correct; but it cannot be shown to be convincing in the abstract. It raises three questions in particular.

- Perhaps relative position is also what workers carry about with respect to the new, legally granted benefit; perhaps this too is a positional good. Many goods have a mixture of positional and nonpositional features. It does seem reasonable to say that such goods as job security, health care benefits, and leisure time have strong nonpositional features. It is important to have these things regardless of what other people have; an increase in any of them, far more than an increase in money, is an independent good. But job security, leisure time, and the like also have positional features; to lack (say) job security when everyone else lacks job security is probably better than to lack job security when everyone else has it. For the argument on behalf of the nonwaivable term to be made convincing, it must be true (a) that relative position is what matters with respect to income -- or to whatever else is lost as a result of the nonwaivable term -- but (b) that what matters for the good in question, such as job security, is not relative but absolute position. Perhaps we can conclude that the nonpositional features of job security, health care benefits, and leisure time are enough to give the argument a kind of presumptive validity.

- It is possible that a nonwaivable right to a certain largely nonpositional good, such as job security, will led not only to reductions in income (by hypothesis a positional good) but also to reductions in nonpositional goods (vacation leave, sick leave, health care, parental leave). If the grant of one nonpositional good leads to a decrease in others, there will be nothing to celebrate. There is an empirical agenda here: When government creates a mandatory benefit, 
to what extent is the result to increase not income, but other, less positional benefits associated with employment?

- To what extent is income actually a positional good? . There is considerable evidence that for most people, what matters to perceived well-being is their position in the relevant hierarchy, above a certain minimum level. ${ }^{149}$ Of course for quite poor workers, absolute income may be what matters. In poor nations, absolute increases in wealth affect self-reported happiness levels, not relative position; and absolute increases affect self-reported happiness levels among the very poor. To the extent that a mandatory term is reducing the income of people with little to live on, they are not likely to be justifiable on the ground that I have offered. Of course few mandatory terms will have this effect.

- The nonwaivable right may impose ancillary social costs. It might, for example, force prices to rise, and the resulting inefficiencies may argue against the nonwaivable term. Even when workers are benefited as a result, the term might not be justified on balance; an increase in prices is hardly good news for workers (especially poor ones) and if unemployment increase as well, the nonwaivable term may not be worthwhile.

In light of these points, an understanding of the importance of relative position does not create a decisive argument for nonwaivable terms in employment law. But it does raise a possibility, overlooked in conventional discussions of these problems: even if such terms create a dollar-for-dollar reduction in wages, workers may benefit as a result.

\section{Conclusion}

My basic goal in this Article has been to bring a better understanding of human behavior to bear on the three principal options for employment law: waivable employers' rights, waivable workers' rights, and nonwaivable rights. Contrary to the Coase theorem, the default rule is likely to matter a great deal. Contrary to the standard view in law and economics, workers are loss averse. They will be reluctant to give up rights and goods that have been initially allocated to them - a point confirmed by employers' reluctance to decrease wages, even during a recession. ${ }^{150}$ Contrary to the conventional wisdom, workers do not understand that the current system is "at will," even though the law to this effect is well established. Contrary to the reflexive antipaternalism of many lawyers and economists, workers are likely to have difficulty in deciding whether to waive their rights, and hence the case for nonwaivable terms, defended in behavioral terms, is far more plausible than it appears, defended in terms of simple redistribution. Contrary to the standard economic wisdom, workers often care about relative position, not absolute position. Contrary to standard legal practice, waivable workers' rights represent an attractive alternative in many contexts, responsive in particular to workers' lack of information. Contrary to a standard legal view, the difference between legal hostility to individual waivers and legal receptivity to union waivers is defensible on the ground that unions are less likely to suffer from myopia and other forms of bounded rationality.

More particularly, we have seen that the initial allocation of the legal right may well matter, both because of the endowment effect and because of the transactions costs of changing it. The question whether to allow waivers by individual workers turns largely on questions about

\footnotetext{
${ }^{149}$ See id; see also Robert Frank, Luxury Fever (1999).

${ }^{150}$ See Bewley, supra note.
} 
information; some of these questions are complex and subtle. We have also seen significant differences between individual and collective waivers. Many of the concerns about individual waivers are weakened when workers are waiving as a group. In both the individual and collective contexts, objections to allowing waiver might be met, not by banning waivers entirely, but via procedural or substantive constraints.

We have seen more particularly that waivable workers' rights represent a distinctive, promising, and insufficiently explored approach to the law of labor relations. A system of this kind will often be preferable to the more standard alternatives of waivable employers' rights and nonwaivable workers' rights. To the extent that workers might undervalue the rights initially allocated to them, and sell them for a price that is too low, it is sensible to consider, as an alternative to a ban on waiver, a system of constrained waiver, ranging from requirements of disclosure, to a cooling-off period, to legal floors on what employees will receive through the relevant trades.

In the area of the contract at will, I have suggested that legislatures should experiment with waivable for cause rules, and also that courts should move in this direction by penalizing employers who lead employees to believe that they have protection against at will discharge (as, for example, through promises of "permanent" employment and through statements of "policy" to retain all good employees). If progress is to be made in improving worker well-being without introducing excessive rigidity into the labor market, the best route for the future will consist of more creative experiments with waivable workers' rights.

For many problems, it would make sense to combine a system of nonwaivable statutory minima, consisting of safeguards that no worker should lack, alongside an ample set of waivable workers' rights, subject to bargaining. There is room for disagreement about what should count as the nonwaivable minima and what should count as the waivable workers' rights; it is in identifying the content of the categories, rather than in settling on the basic approach, that reasonable disputes will arise. An approach of this kind is no blueprint, but it suggests a general orientation that could provide the foundation for a new system of employment law in a wide range of areas. Equally important, an understanding of the nature of workers' judgments and motivations, and the possible grounds for choosing among the legal options, could provide the basis for orienting future inquiry, and for making progress on the issues, many of them empirical in nature, that remain. 
R eaders with comments should address them to:

C ass R. Sunstein

Karl N. L lewellyn D istinguished Service Professor of Jurisprudence University of C hicago L aw School

$1111 \mathrm{E}$ ast 60th Street

Chicago, IL 60637 
Chicago W orking Papers in L aw and E conomics (Second Series)

1. W illiam M. Landes, Copyright Protection of L etters, D iaries and $O$ ther Unpublished W orks: A $n$ E conomic A pproach (J uly 1991).

2. Richard A. E pstein, The Path to The T. J. H ooper: The Theory and $H$ istory of $C$ ustom in the $L$ aw of T ort (A ugust 1991).

3. Cass R. Sunstein, $O \mathrm{n}$ Property and Constitutionalism (September 1991).

4. Richard A. Posner, Blackmail, Privacy, and Freedom of Contract (February 1992).

5. Randal C. Picker, Security Interests, M isbehavior, and Common Pools (F ebruary 1992).

6. Tomas J. Philipson \& Richard A. Posner, O ptimal Regulation of AIDS (A pril 1992).

7. D ouglas G. Baird, Revisiting A uctions in Chapter 11 (A pril 1992).

8. W illiam M. Landes, Sequential versus Unitary Trials: A $n$ E conomic A nalysis (July 1992).

9. W illiam M. Landes \& Richard A. Posner, The Influence of E conomics on L aw: A Q uantitative Study (A ugust 1992).

10. A lan 0 . Sykes, The W elfare $E$ conomics of I mmigration $L$ aw: $A$ Theoretical Survey W ith A $n$ A nalysis of U.S. Policy (September 1992).

11. D ouglas G . B aird, $1992 \mathrm{~K}$ atz L ecture: R econstructing C ontracts (N ovember 1992).

12. G ary S. Becker, The E conomic W ay of Looking at Life (January 1993).

13. J. M ark Ramseyer, C redibly Committing to Efficiency W ages: Cotton Spinning Cartels in Imperial Japan (M arch 1993).

14. C ass R. Sunstein, E ndogenous Preferences, E nvironmental L aw (A pril 1993).

15. Richard A. Posner, W hat Do Judges and Justices $M$ aximize? (T he Same T hing E veryone E Ise D oes) (A pril 1993).

16. L ucian A rye B ebchuk and Randal C. Picker, Bankruptcy Rules, $M$ anagerial Entrenchment, and Firm-Specific H uman C apital (A ugust 1993). 
17. J. M ark Ramseyer, Explicit R easons for Implicit Contracts: The L egal L ogic to the Japanese M ain B ank System (A ugust 1993).

18. W illiam M . L andes and Richard A. Posner, The E conomics of A nticipatory A djudication (September 1993).

19. Kenneth W. D am, The E conomic Underpinnings of Patent L aw (September 1993).

20. A lan 0 . Sykes, An Introduction to Regression A nalysis (O ctober 1993).

21. Richard A. Epstein, The U biquity of the Benefit Principle (M arch 1994).

22. Randal $\mathrm{C}$. Picker, A $\mathrm{n}$ Introduction to $\mathrm{G}$ ame Theory and the L aw (June 1994).

23. W illiam M . Landes, Counterclaims: A n E conomic A nalysis (June 1994).

24. J. M ark Ramseyer, The $\mathrm{M}$ arket for $\mathrm{C}$ hildren: Evidence from E arly M odern Japan (A ugust 1994).

25. Robert H . G ertner and G eoffrey P. M iller, Settlement E scrows (A ugust 1994).

26. Kenneth W. Dam, Some E conomic Considerations in the Intellectual Property Protection of Software (A ugust 1994).

27. C ass R. Sunstein, Rules and Rulelessness, (O ctober 1994).

28. D avid Friedman, M ore Justice for L ess M oney: A Step B eyond Cimino (D ecember 1994).

29. Daniel Shaviro, Budget D eficits and the Intergenerational D istribution of L ifetime Consumption (January 1995).

30. Douglas $G$. Baird, The $L$ aw and E conomics of Contract D amages (F ebruary 1995).

31. Daniel Kessler, Thomas M eites, and G eoffrey P. M iller, Explaining Deviations from the Fifty Percent Rule: A M ultimodal A pproach to the Selection of $\mathrm{C}$ ases for Litigation (M arch 1995).

32. G eoffrey P. M iller, D as Kapital: Solvency Regulation of the A merican B usiness E nterprise (A pril 1995).

33. Richard C raswell, Freedom of C ontract (A ugust 1995).

34. J. M ark Ramseyer, Public C hoice (N ovember 1995).

35. K enneth W. Dam, Intellectual Property in an A ge of Software and Biotechnology (N ovember 1995). 
36. C ass R. Sunstein, Social Norms and Social Roles (January 1996).

37. J. M ark Ramseyer and E ric B. Rasmusen, Judicial Independence in Civil L aw R egimes: E conometrics from Japan (January 1996).

38. Richard A. E pstein, T ransaction C osts and Property Rights: $\mathrm{O} r$ D o G ood Fences $M$ ake $G$ ood N eighbors? (M arch 1996).

39. C ass R. Sunstein, The Cost-B enefit State ( $M$ ay 1996).

40. W illiam M . L andes and Richard A. Posner, The E conomics of $L$ egal $D$ isputes $O$ ver the $O$ wnership of $W$ orks of $A$ rt and $O$ ther Collectibles (July 1996).

41. John R. L ott, Jr. and D avid B. M ustard, C rime, D eterrence, and Right- to- $\mathrm{C}$ arry $\mathrm{C}$ oncealed $\mathrm{H}$ andguns (A ugust 1996).

42. C ass R. Sunstein, $\mathrm{H}$ ealth- $\mathrm{H}$ ealth T radeoffs (September 1996).

43. $G$. B aird, The H idden Virtues of $C$ hapter 11: A $n$ O verview of the $L$ aw and $E$ conomics of Financially D istressed Firms ( $M$ arch 1997).

44. Richard A. Posner, C ommunity, W ealth, and E quality ( $M$ arch 1997).

45. W illiam M . Landes, The A rt of $L$ aw and E conomics: $A n$ A utobiographical E ssay (M arch 1997).

46. C ass R. Sunstein, B ehavioral A nalysis of L aw (A pril 1997).

47. John R. L ott, Jr. and K ermit D aniel, Term L imits and Electoral Competitiveness: E vidence from California's State L egislative Races (M ay 1997).

48. Randal C. Picker, Simple $G$ ames in a Complex World: A $G$ enerative A pproach to the A doption of N orms (June 1997).

49. Richard A. Epstein, Contracts Small and Contracts Large: Contract $L$ aw through the $L$ ens of $L$ aissez- $F$ aire (A ugust 1997).

50. C ass R. Sunstein, Daniel Kahneman, and David Schkade, A ssessing Punitive $D$ amages (with Notes on Cognition and Valuation in L aw) (D ecember 1997).

51. W illiam M. Landes, Lawrence Lessig, and M ichael $E$. Solimine, Judicial Influence: A Citation A nalysis of Federal C ourts of A ppeals Judges (J anuary 1998).

52. John R. L ott, Jr., A Simple Explanation for W hy Campaign Expenditures are Increasing: The Government is G etting Bigger (F ebruary 1998). 
53. Richard A. Posner, Values and C onsequences: A $n$ Introduction to $E$ conomic A nalysis of $L$ aw (M arch 1998).

54. D enise D iPasquale and E dward L. G laeser, Incentives and Social C apital: A re H omeowners Better C itizens? (A pril 1998).

55. Christine Jolls, C ass R. Sunstein, and Richard Thaler, A Behavioral A pproach to $L$ aw and $E$ conomics (M ay 1998).

56. John R. L ott, J r., D oes a $\mathrm{H}$ elping $\mathrm{H}$ and Put $\mathrm{O}$ thers $\mathrm{At}$ Risk?: A ffirmative Action, Police Departments, and Crime ( $M$ ay 1998).

57. C ass R. Sunstein and E dna U IImann-M argalit, Second-O rder D ecisions (June 1998).

58. Jonathan M. Karpoff and John R. L ott, J r., Punitive D amages: Their D eterminants, E ffects on Firm V alue, and the Impact of Supreme Court and Congressional A ttempts to Limit A wards (July 1998).

59. Kenneth W. Dam, Self-H elp in the Digital Jungle (A ugust 1998).

60. John R. L ott, Jr., H ow D ramatically Did W omen's Suffrage Change the Size and Scope of G overnment? (September 1998)

61. Kevin A. Kordana and E ric A. Posner, A Positive Theory of Chapter 11 (O ctober 1998)

62. D avid A. W eisbach, Line D rawing, D octrine, and E fficiency in the T ax L aw (N ovember 1998)

63. Jack L. G oldsmith and E ric A. Posner, A T heory of C ustomary International L aw (N ovember 1998)

64. John R. Lott, Jr., Public Schooling, Indoctrination, and T otalitarianism (D ecember 1998)

65. C ass R. Sunstein, Private B roadcasters and the Public Interest: N otes T oward A "T hird W ay" (January 1999)

66. Richard A. Posner, An E conomic A pproach to the $L$ aw of E vidence ( $F$ ebruary 1999)

67. Yannis Bakos, E rik Brynjolfsson, Douglas Lichtman, Shared Information G oods (F ebruary 1999)

68. Kenneth W. Dam, Intellectual Property and the A cademic E nterprise (F ebruary 1999)

69. G ertrud M. Fremling and Richard A. Posner, Status Signaling and the $L$ aw, with Particular A pplication to Sexual $H$ arassment (M arch 1999) 
70. C ass R. Sunstein, M ust Formalism Be D efended E mpirically? (M arch 1999)

71. Jonathan M. Karpoff, John R. L ott, Jr., and G raeme Rankine, Environmental Violations, L egal Penalties, and Reputation Costs (M arch 1999)

72. M atthew D. Adler and E ric A. Posner, Rethinking CostBenefit A nalysis (A pril 1999)

73. John R. Lott, Jr. and W illiam M. L andes, M ultiple Victim Public Shooting, Bombings, and Right-to- $C$ arry Concealed $\mathrm{H}$ andgun Laws: Contrasting Private and Public Law Enforcement (A pril 1999)

74. Lisa Bernstein, The Q uestionable E mpirical Basis of A rticle 2's Incorporation Strategy: A Preliminary Study (M ay 1999)

75. Richard A. E pstein, D econstructing Privacy: and Putting It Back T ogether A gain (M ay 1999)

76. W illiam M . L andes, W inning the A rt L ottery: The E conomic R eturns to the $\mathrm{G}$ anz Collection (M ay 1999)

77. Cass R. Sunstein, D avid Schkade, and D aniel Kahneman, Do People W ant O ptimal D eterrence? (June 1999)

78. Tomas J. Philipson and Richard A. Posner, The L ong-R un $G$ rowth in $O$ besity as a Function of T echnological Change (June 1999)

79. D avid A. W eisbach, I roning $O$ ut the F lat T ax (A ugust 1999)

80. E ric $A$. Posner, $A$ T heory of $C$ ontract $L$ aw under $C$ onditions of Radical Judicial E rror (A ugust 1999)

81. David Schkade, Cass R. Sunstein, and Daniel Kahneman, A re Juries Less Erratic than Individuals? Deliberation, Polarization, and Punitive D amages (September 1999)

82. C ass R. Sunstein, N ondelegation C anons (September 1999)

83. Richard A. Posner, The Theory and Practice of Citations A nalysis, with Special Reference to $L$ aw and Economics (September 1999)

84. Randal C. Picker, Regulating N etwork Industries: A L ook at Intel (O ctober 1999)

85. C ass R. Sunstein, Cognition and Cost-Benefit A nalysis (O ctober 1999) 
86. D ouglas G. Baird and Edward R. M orrison, O ptimal T iming and Legal Decisionmaking: The $C$ ase of the $L$ iquidation D ecision in Bankruptcy (O ctober 1999)

87. G ertrud M . F remling and Richard A. Posner, M arket Signaling of Personal C haracteristics (N ovember 1999)

88. M atthew D. A dler and E ric A. Posner, Implementing Cost$B$ enefit A nalysis W hen Preferences A re D istorted ( $N$ ovember 1999)

89. Richard A. Posner, O rwell versus H uxley: E conomics, T echnology, Privacy, and Satire (N ovember 1999)

90. David $A$. W eisbach, Should the Tax Law Require $C$ urrent A ccrual of Interest on Derivative Financial Instruments? (D ecember 1999)

91. C ass R. Sunstein, The L aw of $G$ roup Polarization (D ecember 1999)

92. E ric A. Posner, A gency $M$ odels in $L$ aw and E conomics (January 2000)

93. Karen Eggleston, E ric A. Posner, and Richard Zeckhauser, Simplicity and Complexity in Contracts (January 2000)

94. D ouglas G. Baird and Robert K. Rasmussen, B oyd's L egacy and Blackstone's $G$ host (F ebruary 2000)

95. D avid Schkade, C ass R. Sunstein, Daniel Kahneman, D eliberating about D ollars: The Severity Shift (F ebruary 2000)

96. Richard A. Posner and E ric B. Rasmusen, Creating and E nforcing N orms, with Special R eference to Sanctions ( $M$ arch 2000)

97. D ouglas Lichtman, Property Rights in E merging Platform T echnologies (A pril 2000)

98. Cass R. Sunstein and Edna U IImann-M argalit, Solidarity in Consumption (M ay 2000)

99. David A. W eisbach, An Economic A nalysis of Anti-T ax A voidance $L$ aws ( $M$ ay 2000)

100. $C$ ass $R$. Sunstein, $H$ uman B ehavior and the $L$ aw of W ork (June 2000) 